\title{
COMPARATIVE PHYTOCHEMICAL AND BIOLOGICAL INVESTIGATION OF FIVE GLYCINE MAX (L.) MERRILL GENOTYPES
}

\author{
HOWAIDA I ABD-ALLA ${ }^{1 *}$, HANAN A. A TAIE ${ }^{2}$, MARWA M ABD-ELMOTALEB ${ }^{3}$
}

${ }^{1}$ Department of Chemistry of Natural Compounds, Division of Drugs and Pharmaceutical Industries, National Research Centre (NRC), Cairo, Egypt. ${ }^{2}$ Department of Plant Biochemistry, Division of Agriculture and Biological Researches, National Research Centre, Cairo, Egypt. ${ }^{3}$ Department of Medical plants, National Nutrition Institute, The General Organization for Teaching Hospitals and Institutes, Ministry of Health, Cairo, Egypt. Email: howaida_nrc@yahoo.com

Received: 17 October 2018, Revised and Accepted: 03 December 2018

\section{ABSTRACT}

Objective: Soybean (Glycine max L. Merrill) is the world's most important consumed seed legume. The objectives of the present study were to determine the variability in phytochemical composition and biological activities between five genotypes of $G$. max.

Methods: Lipoidal matters were determined using glucose (GLC). Amino acids were detected by the amino acid analyzer. The phytoconstituents present within each ethanol extract was investigated by gas chromatography-mass spectrometry. The amount of total phenolics, flavonoids, and tannins was analyzed using a spectrophotometric technique, based on Folin-Ciocalteu reagent, aluminum chloride colorimetric assay, and the modified vanillin hydrochloric acid method, respectively. Quercetin, catechin, and gallic acid were used as standard compounds, respectively. Isoflavones content were detected by high-performance liquid chromatography (HPLC)/photodiode array (PDA). The radical scavenging and antioxidant capacity of the genotypes using different in vitro analytical assays such as 2,2-diphenyl,1-picryl hydrazyl, 2,2'-Azino-bis(3-ethylbenzothiazoline-6-sulphonic acid, reducing power, metal chelating, and ferric reducing anti-oxidant power. Butyl hydroxyl toluene and trolox were used as the reference antioxidant radical scavenger compounds. Antitumor activity was evaluated by detecting the viability of Ehrlich ascites carcinoma cells on four different concentrations $(1-5 \mathrm{mg} / \mathrm{mL})$.

Results: GLC analysis showed the high value of total unsaturated fatty acids and 16 amino acids including glutamic acid with the highest concentration. The variation between genotypes according to their chemical composition of the aldehydes, esters, ketones, alcoholics, and carboxylic content were reported. HPLC/PDA referred to the presence of daidzein, genistein, and in all genotypes.

Conclusion: The results confirm the higher value of phytoconstituents of the genotype Giza 35 and Giza 21 as well as their better bioactivity.

Keywords: Glycine max, Antioxidant, Antitumor, Glucose, Amino acids, Gas chromatography-mass spectrometry, High-performance liquid Chromatography/photodiode array.

(C) 2019 The Authors. Published by Innovare Academic Sciences Pvt Ltd. This is an open access article under the CC BY license (http://creativecommons. org/licenses/by/4. 0/) DOI: http://dx.doi.org/10.22159/ajpcr.2019.v12i2.30322

\section{INTRODUCTION}

Soybean (Glycine max (L.) Merrill) has been a part of traditional food for the human population in eastern part of the world and recently it has become popular in other parts of the world [1]. It is one the most widely researched and health-promoting cheapest food for human and animals. Glycine genus is a unique genus. There is an increasing interest for this genus due to its biological effects including estrogen-like activity, prevention of breast, prostate, and colon cancer [2,3]. Other activities as prevention of menopausal symptoms, anti-osteoporosis, and antioxidant were reported [4,5]. Soybean is an important crop following cotton, in Egypt. It is a fundamental storehouse of many chemical metabolites which are divided into two categories, primary and secondary metabolites. The secondary metabolites including lipids, flavonoids, phenols, and tannins are the compounds produced by the plant as defense chemicals [6]. These metabolites have important properties as anti-aging, antiinflammatory, antioxidant, and anti-proliferative agents $[4,5]$. There are more than 25 genotypes of $G$. max used in Egypt including the common genotypes; Giza $22\left(\mathrm{G}_{22}\right)$, Giza $35\left(\mathrm{G}_{35}\right)$, Giza $82\left(\mathrm{G}_{82}\right)$, and Giza $111\left(G_{111}\right)$. These genotypes were selected according to their harvest season in May 2014. It is recommended to cultivate genotype $G_{82}$ in the delta of Egypt [[6]. $G_{22}$ is advised to be cultivated in upper and middle Egypt regions. $G_{35}$ and $G_{111}$ are recommended to cultivate in a new land in Nuba ria. The present study aimed to detect the variation between the five used genotypes of $G$. max. Four genotypes $\left(G_{22}, G_{35}\right.$,
$\mathrm{G}_{82}$, and $\mathrm{G}_{111}$ ) are locally grown in Egypt, and the fifth one (Crawford) was imported from the USA.

\section{MATERIALS AND METHODS}

\section{Plant materials}

G. $\max$ (L.) Merrill seeds of five genotypes of $\left(\mathrm{G}_{22}, \mathrm{G}_{35}, \mathrm{G}_{82}, \mathrm{G}_{111}\right.$, and Crawford) were purchased from Agriculture Research Centre, Giza, Egypt. The pedigree of soybean genotypes was as follows: Giza $22\left(G_{22}\right)$ was Forrest x Crawford, Giza $35\left(\mathrm{G}_{35}\right)$ was Crawford x Celest, Giza 82 $\left(\mathrm{G}_{82}\right)$ was Crawford x Maplepresto, Giza $111\left(\mathrm{G}_{111}\right)$ was Crawford x Celest, and Crawford was Williams x Columbus. The genotypes were collected in the cultivation season of May 2014. The samples were collected in sterile polyethylene bags. The seeds were dried under shade.

\section{Preparation of ethanol extracts}

Fine air-dried powder of each genotype (500 g) was mixed with $80 \%$ ethanol ( $2 \mathrm{~L}$ ) and stirred. It was filtered and the residues were discarded. The resulting extract was evaporated to dryness using rotatory evaporator and stored at $4^{\circ} \mathrm{C}$.

\section{Proximate analyses}

All the following tests were carried out on powdered seeds according to A.O.A.C. [7]. Proximate analyses of moisture, ash, carbohydrates, and proteins content were investigated. 


\section{Chemical composition}

\section{Lipoidal matters of five genotypes}

Saponification of $n$-hexane extract

The powder of the air-dried seeds of each genotype (100 g) was extracted with $n$-hexane in a continuous extraction apparatus. The solvents were evaporated to dryness under reduced pressure at $40^{\circ} \mathrm{C}$. The residue was subjected to saponification by refluxing with $0.5 \mathrm{M}$ alcoholic $\mathrm{KOH}$ in a water bath for $2 \mathrm{~h}$ [8]. After cooling, $50 \mathrm{~mL}$ of water was added, and the solution was extracted with chloroform. The organic phase was washed with water until it became alkali-free and was then dried over anhydrous sodium sulfate.

\section{Preparation of fatty acid methyl esters (FAME)}

The free fatty acids obtained from saponification were subjected to methylation ( $\mathrm{MeOH}, 4 \%-5 \%$ dry $\mathrm{H}_{2} \mathrm{SO}_{4}$ ) for $2 \mathrm{~h}$, extracted with ether, then evaporated and analyzed by glucose (GLC) [9].

\section{Determination of total amino acids content}

Powdered seed (65 mg for each genotype) was put into a hydrolysis tube. Hydrochloric acid (HCL) (6 N, $1 \mathrm{~mL}$ ) was added. The solution was hydrolyzed with $\mathrm{HCl}$ at $110^{\circ} \mathrm{C}$ for $24 \mathrm{~h}$. After removing the acid by evaporation in a rotary evaporator, dilute citrate buffer at $\mathrm{pH} 2.2$ was added and the sample was filtered through Millipore Membranes (USA) with pores of $0.22 \mu \mathrm{m}$. The sample was then injected into the Eppendorf - Germany LC 3000 amino acid analyzer. The following conditions were used. The flow rate was $0.2 \mathrm{~mL} / \mathrm{min}$; the pressure of buffer was from 0 to 50 bars; the pressure of reagent was from 0 to 150 bars, and the reaction temperature was $123^{\circ} \mathrm{C}$.

\section{Gas chromatography-mass spectroscopy (GC/MS)}

The GC-MS analysis of an ethanolic extract of five genotypes was carried out using a Thermo scientific, Trace GC Ultra/ISQ Single Quadrupole MS, TG-5MS fused silica capillary column $(30 \mathrm{~nm} \times 0.251 \mathrm{~mm}, 0.1 \mathrm{~mm}$ film thickness) for GC/MS detector. An electron ionization system with ionization energy of $70 \mathrm{eV}$ was used. Helium gas was used as the carrier gas at a constant flow rate of $1 \mathrm{~mL} / \mathrm{min}$. The injector was operated at $280^{\circ} \mathrm{C}$ and the oven temperature was programmed at an initial temperature $40^{\circ} \mathrm{C}$ (hold $4 \mathrm{~min}$ ) to $280^{\circ} \mathrm{C}$ as a final temperature at an increasing rate of $5^{\circ} \mathrm{C} / \mathrm{min}$ (hold $5 \mathrm{~min}$ ). The peaks in the chromatogram were identified according to their mass spectra. The constituents were identified by comparison of their spectral fragmentation patterns with those of the available database libraries, Wiley (Wiley International, USA) and NIST (Nat. Inst. St. Technol., USA), and/or published data $[10,11]$.

\section{Determination of total polyphenolics, flavonoids, and tannins} content

The total polyphenols content of each seed genotype was determined according to the method described by Meda et al. [12]. The total flavonoids content (TFC) was estimated using the method of Ordoñez et al. [13]. While tannins content were determined using the modified vanillin HCL method as reported by Maxon and Rooney [14].

\section{Detection of isoflavones}

Isoflavones were detected in the five genotypes according to Klejdus et al. [15]. The grounded seeds $(50 \mathrm{~g})$ were mixed with $150 \mathrm{~mL}$ of extraction solvent $(80 \% \mathrm{MeOH}$ in water with $0.1 \% \mathrm{HCl})$. The extraction continued for $60 \mathrm{~min}$ at room temperature in an ultrasonic bath. After extraction, the mixture was filtered on paper filter connected to vacuum and form the filtrate. The $\mathrm{MeOH}$ was separated result an aqueous extract. The remaining solution was re-extracted for an additional $60 \mathrm{~min}$, then re-filtrated, and concentrated as before. The two layers of extracts were joined and hydrolyzed to free isoflavone aglycones. Hydrolysis of the extract was performed by reflux with concentrated $\mathrm{HCl}$ at $\mathrm{pH}=$ zero. The isoflavone aglycone forms were re-extracted with diethyl ether, 4-5 times. The diethyl ether extracts were joined, concentrated and transferred to an Eppendorf tube and stored at $5^{\circ} \mathrm{C}$. The samples were centrifuged for $10 \mathrm{~min}$ at $13.500 \mathrm{rpm}$ at $10^{\circ} \mathrm{C}$ temperature (Centrifuge
Eppendorf mod. $5417 \mathrm{R}$ ). After centrifugation, $100 \mathrm{~mL}$ was injected in high-performance liquid Chromatography (HPLC).

\section{Biological activities}

2,2-diphenyl,1-picrylhydrazyl (DPPH) free-radical scavenging assay

The free-radical scavenging activity using DPPH reagent was determined according to Brand-Williams et al. [16]. Each genotype extract was soluble with $85: 15 \mathrm{v} / \mathrm{v}$ methanol:water. To $0.5 \mathrm{~mL}$ of different concentrations of the extract sample, $1.0 \mathrm{~mL}$ of freshly prepared ethanolic DPPH solution $\left(20 \mu \mathrm{g} / \mathrm{mL}^{-1}\right)$ was added and stirred. The decolorizing process was recorded after 5 min of reaction at $517 \mathrm{~nm}$ and compared with a blank control. Butyl hydroxyl toluene (BHT) was used as a positive control. All samples were analyzed in triplicate. The ability to scavenge the DPPH radical was calculated using the following equation:

DPPH scavenging activity $(\%)=([$ Abs. control-Abs. sample] $\div$ Abs. control) $\times 100$

Where, Abs. control is the absorbance reading of control and Abs. sample is the absorbance reading of the sample.

\section{Reducing power assay}

The method of Oyaizu [17] was used to estimate the reducing power of each genotype G. max seeds. Extract ( $0.5 \mathrm{~mL}$ of different concentrations) was added to phosphate buffer $(2.5 \mathrm{~mL}, 0.2 \mathrm{M}, \mathrm{pH} 6.6)$ and $1 \%$ potassium ferricyanide $(2.5 \mathrm{~mL})$. The mixture was incubated at $50^{\circ} \mathrm{C}$ for $20 \mathrm{~min}$. Aliquots of trichloroacetic acid $(2.5 \mathrm{~mL}, 10 \%)$ were added to the mixture, which was centrifuged at $1000 \mathrm{rpm}$ for $10 \mathrm{~min}$. The upper layer of solution $(2.5 \mathrm{~mL})$ was mixed with distilled water $(2.5 \mathrm{~mL})$ and a freshly prepared $\mathrm{FeCl}_{3}$ solution $(0.5 \mathrm{~mL} 0.1 \%)$. The intensity of the blue-green color was measured at $700 \mathrm{~nm}$. In reducing power assay, the yellow color of the test solution changes to be green depending on the reducing power of test specimen. The presence of reductants in the solution causes the reduction of the ferric/ferricyanide complex to the ferrous form. Therefore, ferrous can be monitored by the measurement of the absorbance at $700 \mathrm{~nm}$. Increased absorbance of their action mixture indicated increased reducing power.

\section{Metal chelating activity assay}

The chelation of ferrous ions by extract of each genotype of G. $\max$ was estimated according to the method of Dinis et al. [18]. Each genotype extract $(0.5 \mathrm{~mL}$ of different concentrations of extract) was added to a solution of $50 \mu \mathrm{L} \mathrm{FeCl}_{2}(2 \mathrm{mM})$. The reaction was initiated by the addition of $200 \mu \mathrm{L}$ ferrozine $(5 \mathrm{mM})$. The mixture was shaken vigorously and left at room temperature for $10 \mathrm{~min}$. After equilibrium had been reached, the absorbance of the solution was measured spectrophotometrically at $562 \mathrm{~nm}$. The following formula was used to calculate the percentage of inhibition of ferrozine-ferrous complex of each sample:

Inhibition $\%=([$ Abs. control - Abs. sample $] \div$ Abs. control $) \times 100$

Where, Abs. control is the absorbance reading of control and Abs. sample is the absorbance reading of the sample.

2,2'-Azino-bis(3-ethylbenzothiazoline-6-sulphonic acid (ABTS) radical scavenging activity

ABTS radical scavenging activity was measured by the ABTS cation decolorization assay as described by Re etal. [19], with some modifications. The stock solutions included $7 \mathrm{mM}$ ABTS solutions and $2.4 \mathrm{mM}$ potassium persulfate solution. The working solution was then prepared by mixing the two stock solutions in equal quantities and allowing them to react for $12 \mathrm{~h}$ at room temperature in the dark. The solution was then diluted by mixing $1 \mathrm{~mL}$ ABTS radical solution with $60 \mathrm{~mL}$ methanol to obtain an absorbance of $0.706 \pm 0.001$ units at $734 \mathrm{~nm}$ using the spectrophotometer. ABTS radical solution was freshly prepared for each assay. The extract of each soybean genotype $(0.5 \mathrm{~mL}$ of different concentrations of extract) was reacted with $2.5 \mathrm{~mL}$ of the ABTS reagent, and the absorbance was taken 
at $734 \mathrm{~nm}$ after $7 \mathrm{~min}$ by spectrophotometer. The ABTS radical cation decolorization assay capacity of the extract and percentage inhibition calculated as ABTS radical scavenging activity.

ABTS $(\%)=([$ Abs. control-Abs. sample $]) \div[$ Abs. control $]) \times 100$

Where, Abs. control is the absorbance reading of control and Abs. sample is the absorbance reading of the sample.

\section{Ferric reducing antioxidant power (FRAP) assay}

The FRAP assay was carried out according to Benzie and Strain [20], with some modifications. Trolox was used as positive control. The stock solutions included $300 \mathrm{mM}$ acetate buffer, $\mathrm{pH} 3.6,10 \mathrm{mM}$ of 2, 4, 6-tripyridyl-s-triazine (TPTZ) solution in $40 \mathrm{mM} \mathrm{HCl}$, and $20 \mathrm{mM}$ $\mathrm{FeCl}_{3} \cdot 6 \mathrm{H}_{2} \mathrm{O}$ solution. The fresh solution was prepared by mixing $25 \mathrm{~mL}$ acetate buffer, $2.5 \mathrm{~mL}$ TPTZ solution, and $2.5 \mathrm{~mL} \mathrm{FeCl}_{3} \cdot 6 \mathrm{H}_{2} \mathrm{O}$ solution and then warmed at $37^{\circ} \mathrm{C}$ before use. Each genotype extract $(500 \mu \mathrm{L}$ of different concentrations) was allowed to react with $2500 \mu \mathrm{L}$ of the FRAP solution for $30 \mathrm{~min}$ in the dark condition. Readings of the colored product (ferrous tripyridyltriazine complex) were then taken at $593 \mathrm{~nm}$. Results were expressed in $\mu$ mol Trolox/100 g dry matter. Additional dilution was required if the FRAP value measured was over the linear range of the standard curve.

\section{In vitro antitumor activity}

To detect the cell viability, blue exclusion test was applied. The suspension of the tumor cells was attained from peritoneal cavities of tumor-bearing mice and then diluted with phosphate buffered saline (PBS, $\mathrm{pH} 7$ ) so that the final preparation comprised $2.5 \times 10^{5}$ cells $/ 0.1 \mathrm{~mL}$. Briefly, in a set of sterile test tubes, aliquots $(0.1 \mathrm{~mL} /$ tube) of the cell preparation were distributed followed by addition of aliquots $(0.8 \mathrm{~mL} /$ tube $)$ of PBS. The investigated samples (dissolved in PBS) were then applied to the tubes in aliquots $(0.1 \mathrm{~mL} /$ tube $)$ at different concentrations of each genotypwe extract. The tubes were incubated at $37^{\circ} \mathrm{C}$ for $2 \mathrm{~h}$ under $5 \% \mathrm{CO}_{2}$. The tubes were centrifuged at $1000 \mathrm{rpm}$ for $5 \mathrm{~min}$, and separated cells were suspended in saline. For each examined tube and control, a new clean, dry small test tube was used, and $0.1 \mathrm{~mL}$ of cells suspension, $0.8 \mathrm{~mL}$ saline, and $0.1 \mathrm{~mL}$ try pan-blue were added and mixed, and then the number of living cells was calculated by hemocytometer slide. Viable cells appeared as unstained bodies while non-viable cells stained blue [21].

\section{RESULTS}

Proximate analyses

It can observe from Table 1 that genotype $G_{111}$ had the highest value of total proteins, carbohydrates, and moisture while genotype $G_{22}$ had the highest value of total ash.

\section{Lipoidal matters}

In the present study, investigation of lipid content of each G. max genotype was carried out using GLC. The unsaponified matters of the five genotypes have hydrocarbons, sterols, and triterpenes. The highest value of hydrocarbons was in genotype Crawford called $n$-hexacosane, $33.83 \%$. The lowest one was in genotype $\mathrm{G}_{111}$ (n-hexadecane, $0.42 \%)$. The ascending order of total hydrocarbons content was Crawford $(59.49 \%)>G_{111}(58.49 \%)>G_{22}(56.85 \%)>G_{82}(52.83 \%)>G_{35}(52.83 \%)$. The highest value for sterols was $\beta$-sitosterol in genotype Crawford $(15.65 \%)$ as shown in Fig. 1 . The lowest value was campesterol (1.12 \%) in genotype Crawford. The ascending order of total sterol content was $\mathrm{G}_{82}(28.04 \%)>\mathrm{G}_{22} \quad(25.35 \%)>$ Crawford $(22.45 \%)>G_{35}(21.42 \%)>G_{111}(17.02 \%)$. There was a-amyrin was detected as the only represented triterpene in all five genotypes. The highest value was in genotype $G_{35}(12.31 \%)$, and the lowest one was in genotype $\mathrm{G}_{22}(1.08 \%)$.

Free fatty acids were classified as saturated such as myristic (C14:0), palmitic (C16:0), stearic acid (C18:0), and unsaturated such as oleic (C18:1), linoleic (C18:2), and linolenic acid (C18:3). The range of fatty

Table 1: Proximate analyses of the five genotypes of G. $\max$

\begin{tabular}{llllll}
\hline Parameter & $\mathbf{G}_{\mathbf{2 2}}$ & $\mathbf{G}_{\mathbf{3 5}}$ & $\mathbf{G}_{\mathbf{8 2}}$ & $\mathbf{G}_{\mathbf{1 1 1}}$ & Crawford \\
\hline Moisture & 6.74 & 6.71 & 6.83 & 6.90 & 6.82 \\
Total ash & 5.82 & 5.52 & 5.41 & 4.70 & 5.20 \\
Proteins & 30.51 & 32.62 & 32.50 & 33.91 & 31.10 \\
Total carbohydrates & 24.62 & 25.01 & 26.21 & 27.10 & 24.52 \\
\hline
\end{tabular}

G. max: Glycine max

Table 2: GLC of fatty acid methyl esters of five genotypes of G. $\max$

\begin{tabular}{llllll}
\hline \multirow{2}{*}{ Compound } & \multicolumn{6}{c}{ Area \% of genotypes } \\
\cline { 2 - 6 } & $\mathbf{G}_{\mathbf{8 2}}$ & $\mathbf{G}_{\mathbf{2 2}}$ & $\mathbf{G}_{\mathbf{3 5}}$ & $\mathbf{G}_{\mathbf{1 1 1}}$ & Crawford \\
\hline Palmitic acid & 18.61 & 36.72 & 35.40 & 35.60 & 32.79 \\
Palmitoleic acid & - & 9.01 & - & 0.98 & - \\
Myristic acid & 1.20 & - & 2.41 & - & - \\
Stearic acid & 2.15 & 7.52 & 6.88 & 7.25 & 3.59 \\
Oleic acid & 33.10 & 36.72 & 13.83 & 7.24 & 45.12 \\
Linoleic acid & 36.99 & - & 38.57 & 44.80 & - \\
Linolenic acid & - & - & 1.12 & 0.92 & - \\
Arachidonic acid & - & - & - & 0.82 & - \\
Total SFA & 21.96 & 44.24 & 44.69 & 42.85 & 36.38 \\
Total USFA & 70.09 & 45.73 & 53.52 & 54.76 & 45.12 \\
\hline
\end{tabular}

SFA: Saturated fatty acids, USFA: Unsaturated fatty acids, G. max: Glycine max, GLC: Gas-liquid chromatography

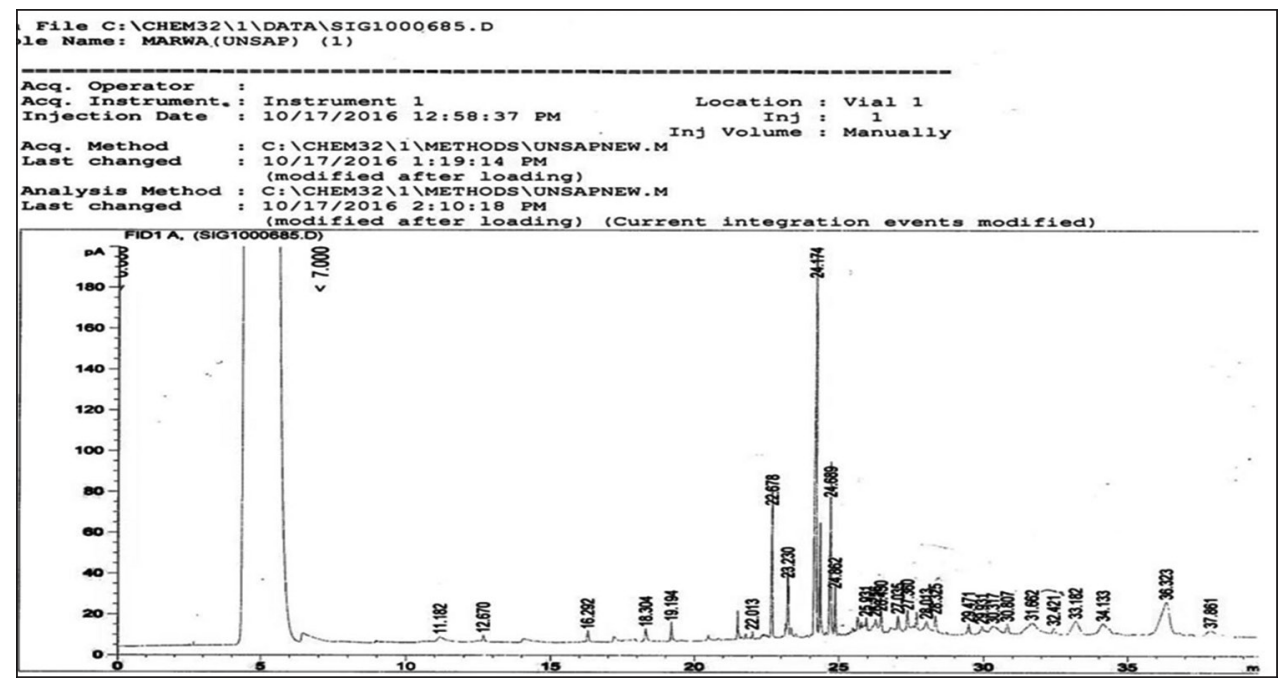

Fig. 1: GLC chromatogram of USM of $G_{35}$ represented the highest value of sterols 
acids contents in five genotypes of G. $\max$ as clarified in Table 2. They were myristic (1.20-2.41), palmitic (18.61-36.72), stearic (2.15-7.52), linoleic (36.99-44.80), linolenic (0.92-1.12), and oleic acid (7.24-45.12\%). The highest value of total unsaturated fatty acids in the investigated genotypes was in $\mathrm{G}_{82}(70.09 \%)$ as shown in Fig. 2.

\section{Amino acids analysis}

The content of the five genotypes of G. max seeds revealed the identification of 16 amino acids. Eight essential amino acids and eight nonessential amino acids, in addition to $\mathrm{NH}_{4}^{+}$, were detected. The concentration of glutamic acid in the five genotypes was the highest value in all the identified amino acids. The range of glutamic acid was within $23.387-13.396 \%$. The order of the concentration of glutamic acid in genotypes was $G_{35}$ (23.387) $>G_{22}(21.562)>G_{111}$ (19.135) $>$ Crawford $(18.407)>G_{82}(13.396 \%)$. Table 3 showed the content of each detected amino acids in the five genotypes.

\section{GC/MS analysis}

A large number of phytochemical were identified in the ethanolic extract of the five genotypes of G. max using (GC-MS). Collectively, 195 compounds of bioactive phytochemicals were identified in the five genotypes based on peak area, retention time $\left(R_{t}\right)$, and molecular formula. The total numbers of the identified compounds were $47\left(\mathrm{G}_{35}\right)$, $42\left(\mathrm{G}_{82}\right), 40\left(\mathrm{G}_{22}\right), 35$ (Crawford), and $31\left(\mathrm{G}_{111}\right)$ and were identified using GC/MS analysis as shown in Tables 4-8. The GC/MS analyses revealed that the predominantly composition of esters (64 compounds), phenolics (23), alcoholics (21), ketones (21), aldehydes (19), heterocyclics (18), alkanes (17), and carboxylic (12 compounds), respectively, that were collectively detected in all genotypes. Hence, esters group represented the highest class percentage in the five genotypes (32.82\%). The order of composition detected by GC/MS was esters (32.82\%)>phenolics (11.79\%)>alcoholics, ketones $(10.77 \%)>$ aldehydes $(9.74 \%)>$ heterocyclics $(9.23 \%)>$ alkanes (8.72\%)>and carboxylic (6.15\%), respectively (Fig. 3).

Giza 35 had the highest number of aldehydes, phenolics, ketones, esters, alcoholics, and carboxylic. Fig. 4 showed a typical GC-MS profile of Giza 35 as the highest genotype having a number of phytochemicals group.

Detection of isoflavones by HPLC with photo-diode-array detector HPLC-photodiode array (PDA)

HPLC with photo-diode-array detector was used to analyze isoflavones in aglycones form in two genotypes of G. max seeds. One of them was local detected in Egypt $\left(\mathrm{G}_{35}\right)$, and the other was imported from USA (Crawford). The comparison between detected compounds made according to $R_{t^{\prime}}$ area percentage and their known molecular weight. $G_{35}$ was selected because it represents that the local genotypes were collected from Egypt, and it had the highest value of total phenolics, flavonoids, antioxidant, and antitumor activity. While Crawford is foreign genotype imported from the USA. The molecular weight of daidzein is $254 \mathrm{~g} / \mathrm{mol}$,

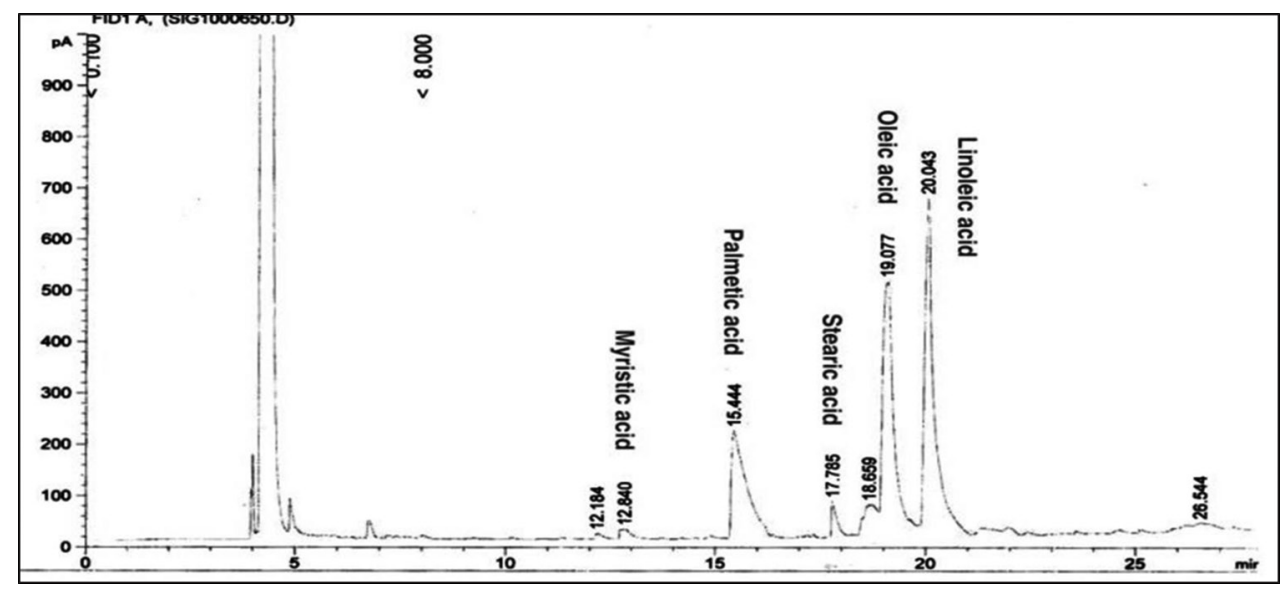

Fig. 2: GLC of FAME of $G_{82}$ represented the highest value of total unsaturated fatty acids

Table 3: Total amino acids content of the five G. $\max$ genotypes

\begin{tabular}{|c|c|c|c|c|c|c|c|c|c|c|}
\hline \multirow[t]{3}{*}{ Amino acids } & \multicolumn{10}{|c|}{ G. max genotypes } \\
\hline & \multicolumn{2}{|l|}{$G_{82}$} & \multicolumn{2}{|l|}{$\mathbf{G}_{22}$} & \multicolumn{2}{|l|}{ Crawford } & \multicolumn{2}{|l|}{$\mathrm{G}_{111}$} & \multicolumn{2}{|l|}{$G_{35}$} \\
\hline & Time (min) & Conc. $\%$ & Time (min) & Conc. $\%$ & Time (min) & Conc. $\%$ & Time (min) & Conc. $\%$ & Time (min) & Conc. \% \\
\hline \multicolumn{11}{|c|}{ Essential amino acids } \\
\hline Phenylalanine & 42.95 & 1.821 & 42.47 & 4.127 & 42.58 & 2.208 & 42.70 & 3.102 & 43.13 & 7.352 \\
\hline Threonine & 15.27 & 0.357 & 15.38 & 0.692 & 15.28 & 0.531 & 15.78 & 0.585 & 15.00 & 0.719 \\
\hline Leucine & - & - & - & - & 37.35 & 1.869 & 37.38 & 2.774 & 38.58 & 1.896 \\
\hline Isoleucine & 37.25 & 1.261 & 37.27 & 2.226 & 36.37 & 0.226 & - & - & 37.57 & 0.179 \\
\hline Histidine & 50.82 & 1.902 & 50.95 & 2.568 & 51.13 & 2.335 & 51.12 & 2.937 & 49.90 & 2.786 \\
\hline Lysine & 53.88 & 1.886 & 54.08 & 2.097 & 54.15 & 1.863 & 54.20 & 2.257 & 53.10 & 4.103 \\
\hline Valine & 31.92 & 0.397 & 32.07 & 0.652 & 32.17 & 0.684 & 32.37 & 0.920 & 32.62 & 0.576 \\
\hline Methionine & 34.65 & 0.034 & 34.68 & 0.265 & 34.92 & 0.390 & 34.93 & 0.718 & 35.83 & 0.032 \\
\hline \multicolumn{11}{|c|}{ None essential amino acids } \\
\hline Alanine & 26.73 & 1.502 & 27.08 & 2.243 & 27.03 & 2.179 & 27.47 & 2.341 & 26.62 & 2.947 \\
\hline Aspartic acid & 12.25 & 1.996 & 12.05 & 3.281 & 11.98 & 2.470 & 12.53 & 2.691 & 11.62 & 3.393 \\
\hline Glutamic acid & 17.93 & 13.396 & 18.65 & 21.562 & 18.58 & 18.407 & 19.08 & 19.135 & 18.20 & 23.387 \\
\hline Glycine & 25.57 & 0.558 & 25.93 & 0.747 & 25.85 & 0.632 & 26.28 & 0.731 & 25.43 & 0.953 \\
\hline Serine & 16.30 & 0.741 & 16.68 & 1.511 & 16.60 & 1.185 & 17.05 & 1.400 & 16.28 & 1.647 \\
\hline Tyrosine & 40.95 & 0.300 & 40.90 & 0.600 & 40.93 & 0.164 & 41.08 & 1.108 & - & - \\
\hline Arginine & 61.60 & 2.698 & 62.18 & 3.265 & 62.50 & 2.641 & 62.60 & 2.682 & 60.47 & 4.197 \\
\hline Proline & 20.75 & 0.281 & 21.25 & 0.434 & 21.13 & 0.405 & 21.60 & 0.479 & 20.78 & 0.781 \\
\hline
\end{tabular}

G. max: Glycine max 
Table 4: GC/MS analysis of local genotype Giza 35 of $G$. max seed

\begin{tabular}{|c|c|c|c|c|c|}
\hline Name of identified compounds & $R_{t}(\min )$ & Nature of compounds & Area\% & M.w & Molecular formula \\
\hline Acetic acid, 2-propenyl ester & 10.59 & Ester & 1.20 & 100 & $\mathrm{C}_{5} \mathrm{H}$ \\
\hline Acetic acid, phenyl ester & 10.70 & Ester & 0.64 & 136 & $\mathrm{C}_{8}^{5} \mathrm{H}_{8}^{8} \mathrm{O}_{2}^{2}$ \\
\hline Pentane, 1-thoxy & 11.08 & Alkane & 0.57 & 116 & $\mathrm{C}_{7} \mathrm{H}_{16} \mathrm{O}$ \\
\hline 2,5-Hexanediol, 2,5-dimethyl & 11.11 & Alcoholic & 0.57 & 146 & $\mathrm{C}_{8} \mathrm{H}_{18}^{16} \mathrm{O}_{2}$ \\
\hline Hydroperoxy diethyl ether & 11.21 & Ester & 1.52 & 106 & \\
\hline Acetic acid, mercapto, 1,2ethanediyl ester & 11.69 & Ester & 0.59 & 210 & $\mathrm{C}_{6} \mathrm{H}_{10} \mathrm{O}_{4}$ \\
\hline Phenol, 2-methoxy & 24.73 & Phenolic & 0.98 & 124 & $\mathrm{C}_{7}^{6} \mathrm{H}_{8} \mathrm{O}_{2}$ \\
\hline Phenol, 4-ethenyl-, acetate & 19.29 & Phenolic & 0.99 & 162 & $\mathrm{C}_{7} \mathrm{H}_{8} \mathrm{O}_{2}$ \\
\hline Cyclohexane methanol- 4-1methylethyl & 21.71 & Alcoholic & 1.30 & 156 & $\mathrm{C}_{10} \mathrm{H}_{20}^{8} \mathrm{O}$ \\
\hline Menthol & 21.73 & Alcoholic & 5.77 & 157 & \\
\hline 2-Methoxy-4-vinylphenol & 23.35 & Phenolic & 0.89 & 150 & $\mathrm{C}_{9} \mathrm{H}$ \\
\hline Phenol, 2,6-dimethoxy & 24.99 & Phenolic & 0.97 & 154 & $\mathrm{C}_{8} \mathrm{H}$ \\
\hline 2,4-dodecadienal & 25.94 & Alkane & 1.24 & 182 & \\
\hline 13-Heptadecyn-1-ol & 25.95 & Alcoholic & 1.36 & 252 & $\mathrm{C}_{17}^{12} \mathrm{H}$ \\
\hline 2,4-Dodecadienal & 26.70 & Aldehyde & 2.08 & 180 & \\
\hline 2,4-Undecadienal & 26.75 & Aldehyde & 2.08 & 166 & $\mathrm{C}_{11}$ \\
\hline 3-Ethoxy-2-butanone & 28.10 & Ketone & 2.46 & 116 & $\mathrm{CH}$ \\
\hline 13-Tetradecenal & 28.24 & Aldehyde & 1.34 & 210 & \\
\hline 11-Pentadecenal & 28.30 & Aldehyde & 1.34 & 224 & $\mathrm{C}_{15}$ \\
\hline 11-Hexadecenal & 28.32 & Aldehyde & 1.34 & 238 & $\mathrm{C}_{16}^{15} \mathrm{H}_{30}^{28} \mathrm{O}$ \\
\hline 1,2-Benzenediol, 3-methoxy & 21.01 & Phenolic & 0.89 & 140 & $\mathrm{C}_{7} \mathrm{H}_{8} \mathrm{O}_{3}$ \\
\hline Phenol, 2,6-bis-1,1-dimethylethyl-4-methyl & 30.99 & Phenolic & 0.95 & 220 & \\
\hline Phenol, 2,4-bis-1,1-dimethylethyl & 31.19 & Phenolic & 0.90 & 200 & \\
\hline $\begin{array}{l}\text { 2,6-di-(t-Butyl) 4-hydroxy-4-methyl-2,5-cyclo } \\
\text { hexadien-1-one }\end{array}$ & 31.70 & Ketone & 0.70 & 236 & \\
\hline 5,8,11,14-Eicosatetraynoic acid & 31.73 & Carboxylic acids & 0.70 & 296 & $\mathrm{C}_{20}$ \\
\hline 2,2,7,7-Tetramethyltri cyclo-4-en-3-one & 32.01 & Ketone & 0.70 & 218 & \\
\hline 1-Acetyl1hydroxy 6,8-dimethyoxynaphthalene-2-(1H)-one & 33.03 & Ketone & 0.69 & 262 & $\mathrm{C}_{14}^{15}$ \\
\hline Methyl4,4,7trimethyl4,7 dihydroindan-6-carboxylate & 33.04 & Carboxylic acids & 35.85 & 220 & $\mathrm{C}_{14}^{14}$ \\
\hline $\begin{array}{l}3 \text { (2,2 Dimethylpropylidene) bicycle-3,3,1-nonane } \\
\text { 2,4-dione }\end{array}$ & 33.05 & Ketone & 35.90 & 221 & $\mathrm{C}_{14}^{14} \mathrm{H}_{20}^{20} \mathrm{O}_{2}^{2}$ \\
\hline Pyran-4-carboxylic acid, 4-4-methoxyphenyl- tetrahydro & 33.70 & Heterocyclic & 0.88 & 236 & $\mathrm{C}_{13} \mathrm{H}$ \\
\hline 2H-Pyran-2,6 (3H)-dione & 33.81 & Alcoholic & 0.85 & 112 & $\mathrm{C}_{5} \mathrm{H}$ \\
\hline 1,2-Benzenedicarboxylic acid, di-thyl ester & 35.49 & Ester & 0.74 & 222 & $\mathrm{C}_{12}^{5} \mathrm{H}_{14}^{6} \mathrm{O}_{4}$ \\
\hline $\begin{array}{l}\text { 2-Furanmethanol, } \\
\text { tetrahydro-5-tri-methyl-5-4-methyl-3-cyclohexen-1-yl }\end{array}$ & 39.81 & Alcoholic & 1.34 & 238 & $\mathrm{C}_{15} \mathrm{H}_{26} \mathrm{O}_{2}$ \\
\hline $\begin{array}{l}\text { 2HPyran-3-ol, } \\
\text { tetrahydro-2,2,6-tri-methyl-6-4methyl-3-cyclohexen-1-yl }\end{array}$ & 39.86 & Alcoholic & 1.34 & 238 & $\mathrm{C}_{15} \mathrm{H}_{26} \mathrm{O}_{2}$ \\
\hline Octadecane & 40.01 & Alkane & 0.34 & 254 & $\mathrm{C}_{18} \mathrm{H}_{38}$ \\
\hline Pentadecanoic acid, 14-methyl, methyl ester & 40.06 & Ester & 2.36 & 270 & $\mathrm{C}_{17}^{18} \mathrm{H}$ \\
\hline Octadecane, 3-ethyl-5-2ethylbutyl & 40.15 & Alkane & 0.56 & 366 & $\mathrm{C}_{26}^{17} \mathrm{H}$ \\
\hline Methyl-1,3dihydro2Hisobenzofuran4carboxylate & 40.16 & Carboxylic acids & 0.96 & 178 & $\mathrm{C}_{10}^{26} \mathrm{H}_{10}^{54} \mathrm{O}_{3}$ \\
\hline 3-Heptyl2ethylhexanoate & 40.20 & Ester & 1.25 & 242 & $\mathrm{C}_{15}^{10} \mathrm{H}_{30}^{10} \mathrm{O}_{2}^{3}$ \\
\hline Fumaric acid, ethyl-4-heptyl ester & 40.21 & Ester & 1.25 & 242 & $\mathrm{C}_{13}^{15} \mathrm{H}_{22}^{30} \mathrm{O}_{4}^{2}$ \\
\hline 8,11-Octadecadienoicacid, methyl ester & 40.22 & Ester & 2.97 & 294 & $\mathrm{C}_{19}^{13} \mathrm{H}_{34}^{22} \mathrm{O}_{2}^{4}$ \\
\hline 9,12-Octadecadienoicacid, methyl ester & 40.23 & Ester & 2.97 & 295 & $\mathrm{C}_{19}^{19} \mathrm{H}_{34}^{34} \mathrm{O}_{2}^{2}$ \\
\hline 13-Octadecenoicacid, methyl ester & 40.24 & Ester & 4.00 & 296 & $\mathrm{C}_{19}^{19} \mathrm{H}_{36}^{34} \mathrm{O}_{2}^{2}$ \\
\hline 9-Octadecenoicacid, methyl ester & 40.26 & Ester & 400 & 295 & $\mathrm{C}_{19}^{19} \mathrm{H}_{36}^{36} \mathrm{O}_{2}^{2}$ \\
\hline Hexadecanoic acid, methyl ester & 41.23 & Ester & 0.92 & 270 & $\mathrm{C}_{17}^{19} \mathrm{H}_{34} \mathrm{O}_{2}^{2}$ \\
\hline
\end{tabular}

$\mathrm{R}_{\mathrm{t}}(\mathrm{min})$ : Retention time in minutes,M.w. Molecular weight, G. max: Glycine max, GC/MS: Gas chromatography-mass spectroscopy

while genistein is $270 \mathrm{~g} / \mathrm{mol}$ and glycitein is $284 \mathrm{~g} / \mathrm{mol}$. In this study, HPLC-PDA analysis showed the presence of isoflavone aglycones, daidzein, glycitein, and genistein in both genotypes $G_{35}$ and Crawford. Daidzein has the highest value. Daidzein was detected in $\mathrm{G}_{35}$ had a higher value than daidzein in Crawford as clarified in Fig. 5. It followed by genistein which had the higher value in $\mathrm{G}_{35}$ than Crawford. There was glycitein which had the lowest value in three detected aglycones. $G_{35}$ has a higher value of glycitein than Crawford as shown in Table 9.

\section{Determination of total polyphenolics, flavonoids, and tannins} content

Table 10 summarized the results of the total content of secondary metabolites in the five genotypes of G. max. Total phenolics content, $\mathrm{TFC}$, and total tannins content were determined using equivalents to gallic acid, quercetin, and catechin, respectively.

The present study showed that $\mathrm{G}_{35}$ recorded the highest value of total phenolic, flavonoid and tannin contents, followed by Crawford, $\mathrm{G}_{111}, \mathrm{G}_{22}$, and $\mathrm{G}_{82}$ respectively. It showed descending value of total phenolics (mg gallic acid equivalent [GAE]/g) and tannins (mg catechin equivalent /g) content. The descending order of total flavonoid content (mg Quercetin equivalent $(\mathrm{QE}) / \mathrm{g}$ ) was $\mathrm{G} 35$ followed by $\mathrm{G}_{111}$, Crawford, $\mathrm{G}_{22}$ and $\mathrm{G}_{82}$, that might be responsible for the highest antioxidant activity of $\mathrm{G}_{35}$.

\section{Biological activity}

Antioxidant activity

Many phytochemical components, especially polyphenols (such as flavonoids, phenolic acids, and tannins) are known to be accountable of the free radical scavenging and antioxidant activities of plants. The antioxidant activity was evaluated using five different assays (DPPH free-radical scavenging, reducing power ability, ABTS radical scavenging, metal chelating, and FRAP). The results were illustrated in Table 11.

The radical scavenging and antioxidant capacity of the genotypes using five analytical assays were evaluated. BHT and Trolox were used as the 
Table 5: GC/MS analysis of local genotype Giza 82 of $G . \max$

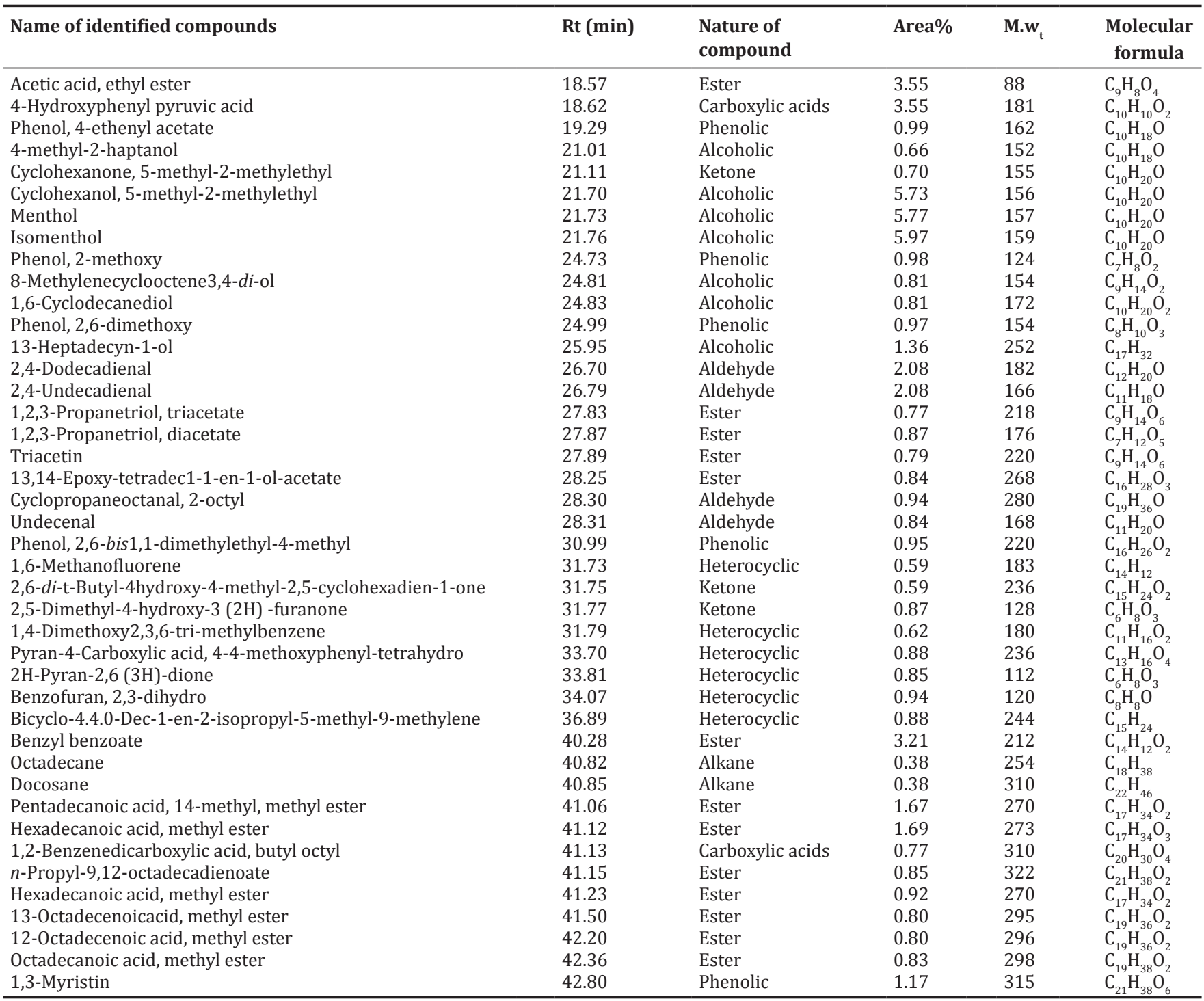

Rt (min): Retention time in minutes, M.w: Molecular weight, GC/MS: Gas chromatography-mass spectroscopy, G. max: Glycine max

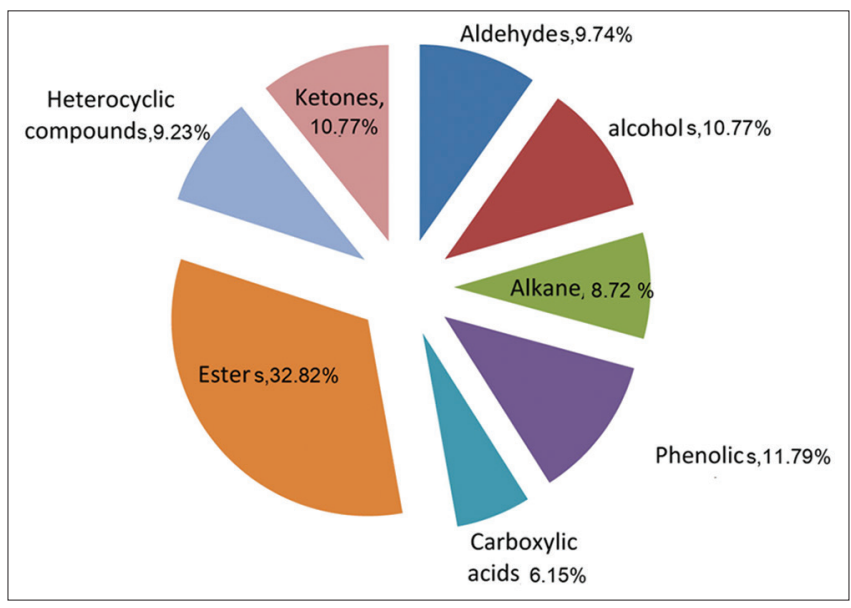

Fig. 3: Pie diagram showing the percentage of phytochemical groups identified in five Glycine max genotypes

reference antioxidant radical scavenger compounds. $\mathrm{G}_{35}$ showed highest antioxidant activity using the five assays as clarified in Table 11, DPPH
(35.95 $\pm 0.32 \%)$, ABTS radical scavenging $(54.59 \pm 0.50 \%)$, and metal chelating ability (61.54 $\pm 0.57 \%)$. Furthermore, the high reducing power ability $(0.509 \pm 0.008)$ and FRAP $(2913 \pm 26.80 \mu \mathrm{mol}$ Trolox/100 g DW $)$ were recorded, followed by $\mathrm{G}_{22}$ in two methods; reducing power ability and ABTS radical scavenging activity. $G_{82}$ had recorded the lowest values in three methods (reducing power ability, metal chelating activity, and FRAP). Furthermore, $G_{111}$ had recorded the lowest ABTS radical scavenging activity while Crawford had recorded lowest DPPH activity. The results showed that genotype $G_{35}$ had the highest content of phenolics and flavonoids as well as the antioxidant activity.

\section{In vitro antitumor activity}

Different concentrations of the five genotypes of $G$. max seeds extract were applied on Ehrlich ascites carcinoma cells.

Table 12 illustrated that $\mathrm{G}_{35}$ exhibited the highest antitumor activity $(14.25 \pm 0.38 \%)$ among the five genotypes of $G$. $\max$ followed by Crawford $(13.18 \pm 0.15 \%)$. The lowest antitumor activity recorded by the genotype $G_{22}(5.8 \pm 0.16 \%)$ at the concentration $5 \mathrm{mg} / \mathrm{mL}$. Fig. 6 showed the effect of different concentrations $(1-5 \mathrm{mg} / \mathrm{mL})$ of genotype $\mathrm{G}_{35}$ seed extract on the viability of Ehrlich ascites carcinoma cells. Data are means of triplicate experiments \pm standard deviation. The range of percentage of dead cells of $1 \mathrm{mg} / \mathrm{mL}$ of the five genotypes of $G$. 
Table 6: GC/MS analysis of local genotype Giza 22 of G. max

\begin{tabular}{|c|c|c|c|c|c|}
\hline Name of identified compounds & $R_{t}(\min )$ & $\begin{array}{l}\text { Nature of } \\
\text { compound }\end{array}$ & Area\% & M.w & $\begin{array}{l}\text { Molecular } \\
\text { formula }\end{array}$ \\
\hline 3-Ethoxy-2-butanone & 24.35 & Ketone & 1.25 & 116 & $\mathrm{C}_{6} \mathrm{H}_{6}$ \\
\hline Phenol, 2-methoxy & 24.73 & Phenolic & 0.98 & 124 & $\mathrm{C}_{7} \mathrm{H}_{8} \mathrm{O}_{2}^{2}$ \\
\hline Menthol & 24.83 & Alcoholic & 5.77 & 157 & $\mathrm{C}_{10} \mathrm{H}_{20}^{8} \mathrm{O}$ \\
\hline 13-Octadecenoic acid & 24.84 & Carboxylic acids & 0.47 & 282 & $\mathrm{C}_{18} \mathrm{H}_{34} \mathrm{O}_{2}$ \\
\hline 2-Decenal & 24.85 & Aldehyde & 0.47 & 154 & $\mathrm{C}_{10}^{18} \mathrm{H}_{18}^{34} \mathrm{O}^{2}$ \\
\hline Tridecanol & 25.85 & Alcoholic & 0.47 & 200 & $\mathrm{C}_{13}^{10} \mathrm{H}_{28} \mathrm{O}$ \\
\hline 2-Undecenal & 28.23 & Aldehyde & 1.02 & 168 & $\mathrm{C}_{11} \mathrm{H}_{20}{ }^{10} \mathrm{O}$ \\
\hline Undecenal & 28.26 & Aldehyde & 1.02 & 168 & $\mathrm{C}_{11}^{11} \mathrm{H}_{20}^{20} \mathrm{O}$ \\
\hline Phenol, 2,6-bis1,1-dimethylethyl-4-methyl & 30.99 & Phenolic & 0.95 & 220 & $\mathrm{C}_{16}^{11} \mathrm{H}_{26}^{20} \mathrm{O}_{2}$ \\
\hline 2,6-di-t-Butyl-4-hydroxy4methyl2,5-cyclo hexadien-1-one & 31.72 & Ketone & 0.82 & 236 & $\mathrm{C}_{15} \mathrm{H}_{24} \mathrm{O}_{2}$ \\
\hline 2-Heptanone-6 (3-acety-12-methyl1cyclopropen-1-yl)-6-mEthyl & 31.75 & Ketone & 0.52 & 222 & $\mathrm{C}_{14}^{15} \mathrm{H}_{22}^{24} \mathrm{O}_{2}^{2}$ \\
\hline 2,5-Dimethyl-4-hydroxy-3 (2H)-furanone & 31.77 & Ketone & 0.87 & 128 & $\mathrm{C}_{6} \mathrm{H}_{8} \mathrm{O}_{3}$ \\
\hline Pyran-4-Carboxylic acid, 4-(4-methoxyphenyl)- tetrahydro & 33.70 & Heterocyclic & 0.88 & 236 & $\mathrm{C}_{13}^{0} \mathrm{H}$ \\
\hline 1,4-Dimethoxy2,3,6-tri-methylbenzene & 33.79 & Heterocyclic & 0.62 & 180 & \\
\hline Diethyl Phthalate & 35.49 & Ester & 0.55 & 222 & $\mathrm{C}_{6}^{5} \mathrm{H}_{14}^{6} \mathrm{O}_{4}^{3}$ \\
\hline 1,2-Benzenedicarboxylic acid, diethyl ester & 35.50 & Ester & 0.55 & 222 & $\mathrm{C}_{6} \mathrm{H}_{14} \mathrm{O}_{4}$ \\
\hline 2H-Pyran-3-ol, tetrahydro2,2,6-trimethyl6 (4methyl3cyclohexen1yl) & 39.80 & Heterocyclic & 0.75 & 238 & $\mathrm{C}_{15}^{0} \mathrm{H}_{26}^{14} \mathrm{O}_{2}$ \\
\hline 2-Furanmethanol, tetrahydro-5-trimethyl-5 (4methyl3cyclohexen1yl) & 39.83 & Alcoholic & 0.75 & 238 & $\mathrm{C}_{15}^{15} \mathrm{H}_{26}^{26} \mathrm{O}_{2}^{2}$ \\
\hline Benzyl benzoate & 40.28 & Ester & 0.48 & 212 & $\mathrm{C}_{14}^{15} \mathrm{H}_{6} \mathrm{O}_{2}$ \\
\hline Octadecane & 40.82 & Alkane & 0.38 & 254 & $\mathrm{C}_{18}^{14} \mathrm{H}$ \\
\hline Docosane & 40.85 & Alkane & 0.38 & 310 & $\mathrm{C}_{22}^{18} \mathrm{H}_{4}$ \\
\hline Hexadecanoic acid, methyl ester & 41.23 & Ester & 0.92 & 270 & $\mathrm{C}_{17}^{22} \mathrm{H}_{34}^{46} \mathrm{O}_{2}$ \\
\hline Phthalic acid, butylhex-3-yl ester & 42.8 & Ester & 0.45 & 306 & $\mathrm{C}_{18}^{17} \mathrm{H}_{26}^{34} \mathrm{O}_{4}^{2}$ \\
\hline Phthalic acid, 5-methylhex-2-yl isobutyl ester & 42.84 & Ester & 0.45 & 320 & $\mathrm{C}_{19}^{18} \mathrm{H}_{28}^{26} \mathrm{O}_{4}^{4}$ \\
\hline Pentadecanoic acid, 13-methyl, methyl ester & 44.06 & Ester & 2.01 & 270 & $\mathrm{C}_{17} \mathrm{H}_{34}^{28} \mathrm{O}_{2}^{4}$ \\
\hline Pentadecanoic acid, 14-methyl, methyl ester & 44.06 & Ester & 2.01 & 270 & $\mathrm{C}_{17} \mathrm{H}_{34}^{34} \mathrm{O}_{2}^{2}$ \\
\hline Nonacosane & 44.98 & Alkane & 0.56 & 311 & $\mathrm{C}_{29}^{17} \mathrm{H}_{60}^{34}$ \\
\hline Hexadecanoic acid & 45.01 & Carboxylic acids & 2.14 & 256 & $\mathrm{C}_{16} \mathrm{H}_{32} \mathrm{O}_{2}$ \\
\hline 1,2-Benzenedicarboxylic acid, dibutyl ester & 45.12 & Ester & 1.24 & 278 & $\mathrm{C}_{16}^{16} \mathrm{H}_{22}^{32} \mathrm{O}_{4}^{2}$ \\
\hline 3,7-Dimethyl4,6-nonandione & 45.27 & Ketone & 0.87 & 184 & $\mathrm{C}_{11} \mathrm{H}_{20} \mathrm{O}_{2}$ \\
\hline Octanoic acid, 1-methyltridecylester & 45.30 & Ester & 0.87 & 296 & $\mathrm{C}_{22} \mathrm{H}_{44} \mathrm{O}_{2}$ \\
\hline 7,10-Octadecadienoic acid, methyl ester & 45.46 & Ester & 2.46 & 294 & $\mathrm{C}_{19}^{19} \mathrm{H}_{34}^{36} \mathrm{O}_{2}^{2}$ \\
\hline 9,12 -Octadecadienoic acid & 45.48 & Carboxylic acids & 5.06 & 280 & $\mathrm{C}_{18}^{19} \mathrm{H}_{32}^{34} \mathrm{O}_{2}^{2}$ \\
\hline Octadecane, 3-ethyl-5 (2ethylbutyl) & 45.49 & Alkane & 0.5 & 366 & $\mathrm{C}_{26}^{18} \mathrm{H}_{54}^{32}$ \\
\hline 9-Octadecenoic acid & 45.88 & Carboxylic acids & 3.05 & 282 & $\mathrm{C}_{18}^{26} \mathrm{H}_{34}^{54} \mathrm{O}_{2}$ \\
\hline Nonadecane, 9-methyl & 45.96 & Alkane & 0.91 & 282 & $\mathrm{C}_{20}^{18} \mathrm{H}_{42}^{34}$ \\
\hline
\end{tabular}

$\mathrm{R}_{\mathrm{t}}(\mathrm{min})$ : Retention time in minutes, M.w: Molecular weight, GC/MS: Gas chromatography-mass spectroscopy, G. max: Glycine max

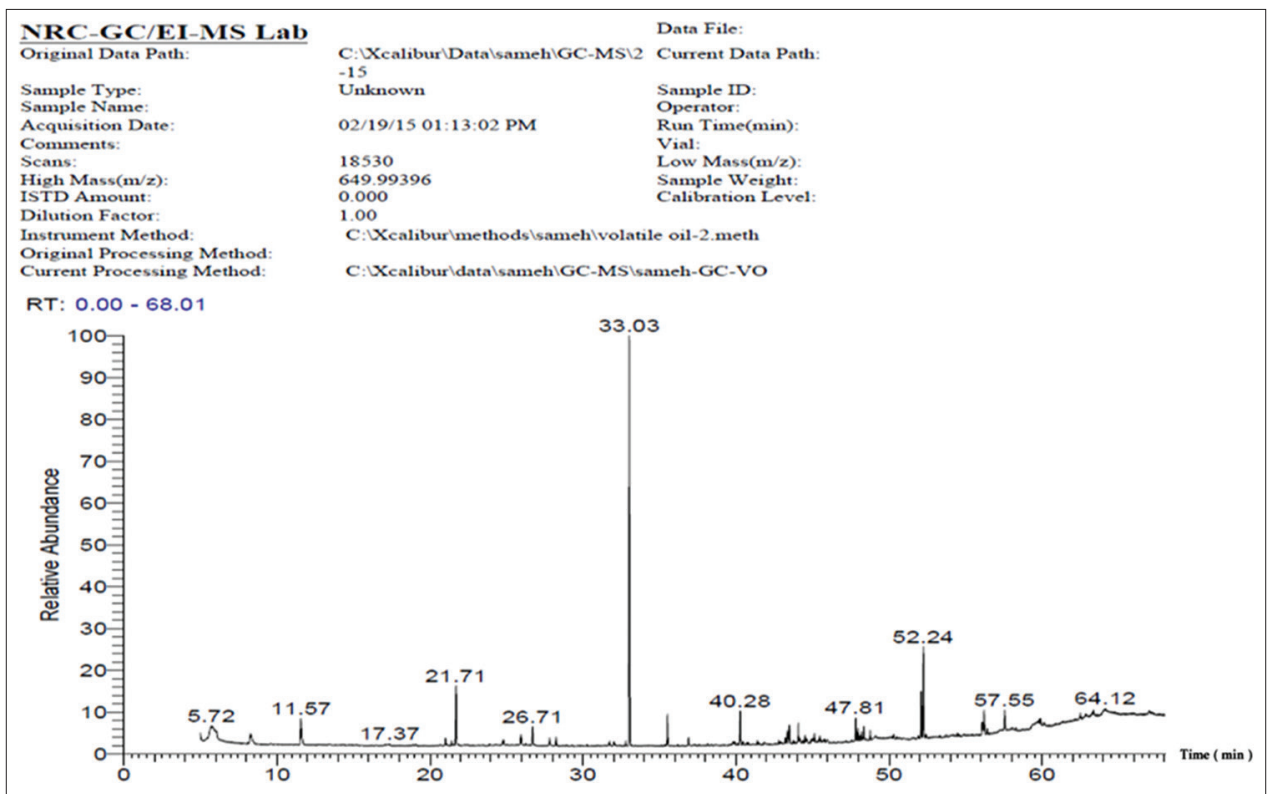

Fig. 4: A typical gas chromatography-mass spectroscopy profile of Giza 35 as the highest genotype having number of phytochemicals 
Table 7: GC/MS analysis of foreign genotype Crawford of G. max seed

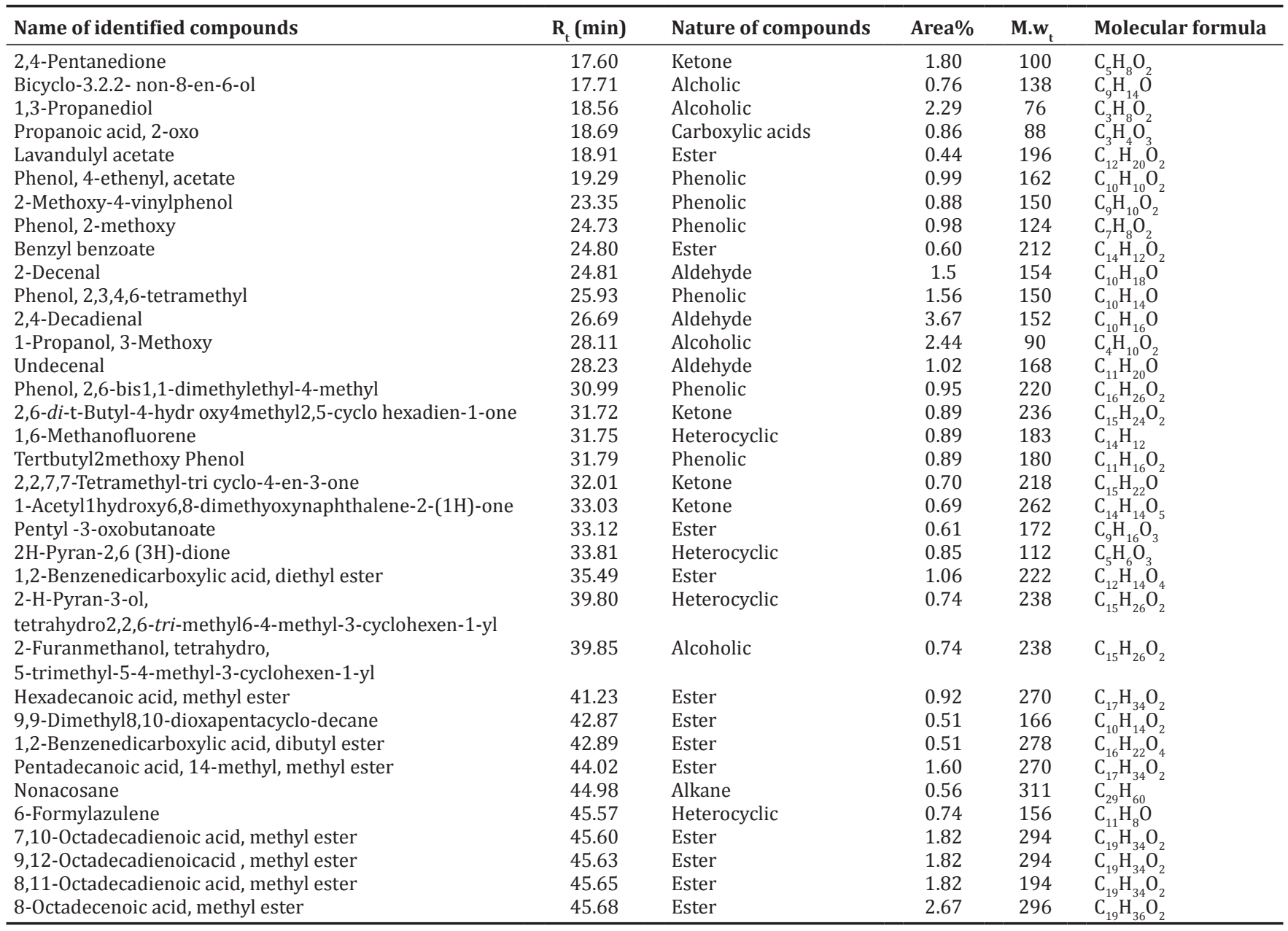

$\mathrm{R}_{\mathrm{t}}(\mathrm{min})$ : Retention time in minutes, M.w $\mathrm{t}$ : Molecular weight, GC/MS: Gas chromatography-mass spectroscopy, G. max: Glycine max

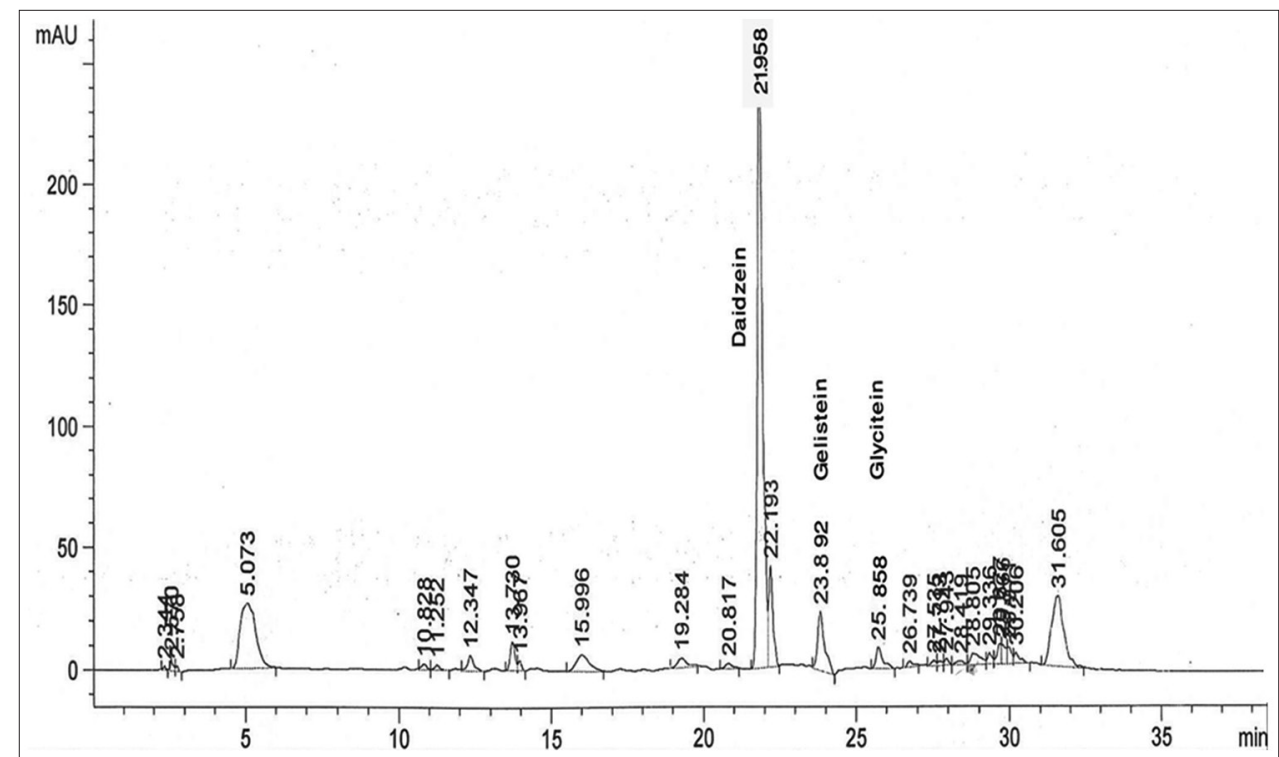

Fig. 5: High-performance liquid chromatography chromatogram of $G_{35}$ hydrolyzed extract

max seeds was $3.27 \pm 0.12-12.00 \pm 0.40 \%$ (Table 12 ). The range of the concentration of dead cells of $2 \mathrm{mg} / \mathrm{mL}$ was $3.55 \pm 0.14-12.35 \pm 0.14 \%$. The concentration of the dead cells of $3 \mathrm{mg} / \mathrm{mL}$ was within $3.64 \pm 0.15-$ $12.83 \pm 0.24 \%$. The range of the concentration of dead cells of $4 \mathrm{mg} /$
$\mathrm{mL}$ was $4.07 \pm 0.09-13.53 \pm 0.13 \%$ and the range of the concentration of dead cells 5 of $\mathrm{mg} / \mathrm{mL}$ was $5.80 \pm 0.16-14.25 \pm 0.38 \%$ (Table 12). It was observed that the antitumor activity of the examined genotypes increased gradually by increasing the concentration of the extract. 
Table 8: Phytocompound identified in of $\mathrm{G}_{111}$ by GC-MS

\begin{tabular}{|c|c|c|c|c|c|}
\hline Name of identified compounds & $R_{t}(\min )$ & $\begin{array}{l}\text { Nature of } \\
\text { compounds }\end{array}$ & Area\% & $\mathbf{M w}_{\mathrm{t}}$ & $\begin{array}{l}\text { Molecular } \\
\text { formula }\end{array}$ \\
\hline Propanoic acid, 2-oxo & 21.69 & Carboxylic acids & 0.86 & 88 & $\mathrm{C}_{3} \mathrm{H}_{4} \mathrm{O} 3$ \\
\hline Phenol, 2-methoxy & 24.73 & Phenolic & 0.98 & 124 & $\mathrm{C}_{7} \mathrm{H}_{8}^{4} \mathrm{O}_{2}$ \\
\hline Docosane & 24.76 & Alkane & 0.69 & 310 & $\mathrm{C}_{22} \mathrm{H}_{46}{ }^{2}$ \\
\hline Phenol, 5-methyl-2-1-methylethyl & 25.92 & Phenolic & 1.33 & 150 & $\mathrm{C}_{10}^{22} \mathrm{H}_{14}^{46} \mathrm{O}$ \\
\hline Thymol & 25.95 & Alcoholic & 1.34 & 152 & $\mathrm{C}_{10}^{10} \mathrm{H}_{14}^{14} \mathrm{O}$ \\
\hline 2-Undecenal & 28.23 & Aldehyde & 0.85 & 168 & $\mathrm{C}_{11}^{10} \mathrm{H}_{20} \mathrm{O}$ \\
\hline 2,6-di-t-Butyl-4-hydroxy4methyl2,5-cyclo hexadien-1-one & 31.72 & Ketone & 0.82 & 236 & $\mathrm{C}_{1} 5 \mathrm{H}_{24} \mathrm{O}_{2}$ \\
\hline 2,2,7,7-Tetramethyl-tri cyclo-undec-4-en-3-one & 32.00 & Ketone & 0.70 & 218 & $\mathrm{C}_{1}^{1} 5 \mathrm{H}_{22}^{24} \mathrm{O}^{2}$ \\
\hline 2-Propen1one, 1 -cyclohexyl & 32.07 & Ketone & 0.70 & 219 & $\mathrm{C}_{1} 5 \mathrm{H}_{22}^{22} \mathrm{O}$ \\
\hline 2H-Pyran-2,6 (3H)-dione & 33.81 & Heterocyclic & 0.85 & 112 & $\mathrm{C}_{5}^{1} \mathrm{H}_{6} \mathrm{O} 3$ \\
\hline Benzene1,2,3,4-tetramethyl-5-1-methylethyl & 36.89 & Heterocyclic & 0.39 & 176 & $\mathrm{C}_{1} 3 \mathrm{H}_{20}$ \\
\hline Cyclohexane, 1,4-dimethyl-2-octade & 38.15 & Alkane & 0.38 & 312 & $\mathrm{C}_{26} \mathrm{H}_{2}$ \\
\hline Acetic acid, 10,11-dihydroxy3,7,11-trimethyldodeca2,6-dienyl ester & 39.8 & Ester & 0.86 & 298 & $\mathrm{C}_{1}^{26} 7 \mathrm{H}_{0}^{2} \mathrm{O}_{4}$ \\
\hline 2-H-Pyran-3-ol, tetrahydro2,2,6-trimethyl6-4-methyl-3-cyclohexen-1-yl & 39.86 & Heterocyclic & 0.86 & 238 & $\mathrm{C}_{1} 5 \mathrm{H}_{26} \mathrm{O}_{2}$ \\
\hline Octadecane & 40.81 & Alkane & 0.34 & 254 & $\mathrm{C}_{18} \mathrm{H}_{8}$ \\
\hline Hexadecanoic acid, methyl ester & 41.23 & Ester & 0.92 & 270 & $\mathrm{C}_{1}^{18} 7 \mathrm{H}_{34}^{8} \mathrm{O}_{2}$ \\
\hline Phthalic acid, hept-4-yl isobutyl ester & 42.8 & Ester & 0.63 & 320 & $\mathrm{C}_{19} \mathrm{H}_{28}^{34} \mathrm{O}_{4}^{2}$ \\
\hline 1,2-Benzenedicarboxylic acid, bis-2-methylpropyl- ester & 42.86 & Ester & 0.63 & 278 & $\mathrm{C}_{16} \mathrm{H}_{22}^{28} \mathrm{O}_{4}^{4}$ \\
\hline Hexadecanoic acid, methyl ester & 44.06 & Ester & 5.62 & 294 & $\mathrm{C}_{19} \mathrm{H}_{34} \mathrm{O}_{2}$ \\
\hline 9,12-Octadecadienoicacid, methyl ester & 44.12 & Ester & 5.62 & 296 & $\mathrm{C}_{19}^{19} \mathrm{H}_{6}^{34} \mathrm{O}_{2}^{2}$ \\
\hline 7,9-Ditertbutyl-1-oxaspiro-4,5-deca-6,9-diene-2,8-dione & 44.14 & Ketone & 0.41 & 276 & $\mathrm{C}_{1} 7 \mathrm{H}_{24}{ }_{24} \mathrm{O} 3$ \\
\hline 3Ethyl3methylnona- decane & 44.99 & Alkane & 0.45 & 310 & $\mathrm{C}_{22}^{1} \mathrm{H}_{46}^{24}$ \\
\hline 1,2-Benzenedicarboxylic acid, di-butyl ester & 45.12 & Ester & 1.58 & 278 & $\mathrm{C}_{16} \mathrm{H}_{22} \mathrm{O}_{4}$ \\
\hline 8,11-Octadecadienoic acid, methyl ester & 47.08 & Ester & 5.62 & 294 & $\mathrm{C}_{19} \mathrm{H}_{34} \mathrm{O}_{2}$ \\
\hline 8-Octadecenoicacid, methyl ester & 47.20 & Ester & 5.27 & 296 & $\mathrm{C}_{19}^{19} \mathrm{H}_{6}{ }_{6} \mathrm{O}_{2}$ \\
\hline Octadecanoic acid, methyl ester & 47.75 & Ester & 1.79 & 298 & $\mathrm{C}_{19}^{19} \mathrm{H}_{3}^{6} \mathrm{O}_{2}^{2}$ \\
\hline Octadecane, 3-ethyl-5-2-ethylbutyl & 47.80 & Alkane & 0.50 & 311 & $\mathrm{C}_{26}^{19} \mathrm{H}_{4}^{8}$ \\
\hline 1,2-Benzenedicarboxylic acid, bis-2-ethylhexyl ester & 47.85 & Ester & 3.39 & 310 & $\mathrm{C}_{24}^{20} \mathrm{H}_{3} \mathrm{O}_{4}$ \\
\hline 1,2-Benzenedicarboxylic acid, $d i$-isooctyl ester & 47.90 & Ester & 3.39 & 319 & $\mathrm{C}_{24}^{24} \mathrm{H}_{8} \mathrm{O}_{4}$ \\
\hline
\end{tabular}

$\mathrm{R}_{\mathrm{t}}(\mathrm{min})$ : Retention time in minutes, M.w $\mathrm{w}_{\mathrm{t}}$ Molecular weight, GC/MS: Gas chromatography-mass spectroscopy

Table 9: HPLC-PDA characteristics ( $\mathrm{R}_{\mathrm{t}}$ and area \%) of the hydrolyzed extract of $G_{35}$ and Crawford

\begin{tabular}{llllll}
\hline Isoflavones & $\mathbf{G}_{\mathbf{3 5}}$ & & & Crawford & \\
\cline { 2 - 3 } \cline { 5 - 6 } & $\mathbf{R}_{\mathbf{t}}$ (min.) & Area \% & & $\mathbf{R}_{\mathbf{t}}$ (min.) & Area \% \\
\hline Daidzein & 21.958 & 14.057 & & 21.936 & 3.922 \\
Genistein & 23.892 & 2.248 & & 23.905 & 1.794 \\
Glycitein & 25.858 & 1.439 & & 25.865 & 0.122 \\
\hline
\end{tabular}

$\mathrm{R}_{\mathrm{t}}(\mathrm{min})$ : Retention time in minutes, HPLC: High-performance liquid

chromatography, PDA: Photodiode array

\section{DISCUSSION}

Significant differences were observed between the genotypes with respect to moisture content, ash, proteins, and carbohydrates content (Table 1). The moisture ranged from 6.71 to $6.90 \%$. $G_{111}$ had the highest moisture content, but $\mathrm{G}_{22}$ and $\mathrm{G}_{35}$ had the lowest content. Silva et al. [22] reported the moisture percentage of G. max (State of Goias), and it was $5.60 \%$. These differences in moisture content may be due to the conditions of drying the grain after harvest, storage period, and the ability of the grains to lose moisture [23]. Protein content was ranged from 30.5 to $33.9 \%$. $\mathrm{G}_{111}$ had the highest protein content, while $G_{22}$ had the lowest content. Silva et al. [22] found that soybean with yellow seed coat (in the State of Goiás) had protein content $40.4 \%$. The total carbohydrates content was ranged from 24.5 to $27.1 \%$. Vieira et al. [24] evaluated amino acids composition of six genotypes grown in Campinas and they ranged from $29.81 \%$ to $33.33 \%$. In the current work, genotype $\mathrm{G}_{111}$ has the highest percentage of total proteins, carbohydrates, and moisture. Concerning to lipoidal matters, the total identified hydrocarbons were $52.83-59.49 \%$, total identified sterols $17.02-28.04 \%$, and the total identified triterpenes $1.08-12.31 \%$. Unsaturated fats are considered the healthy fats and they

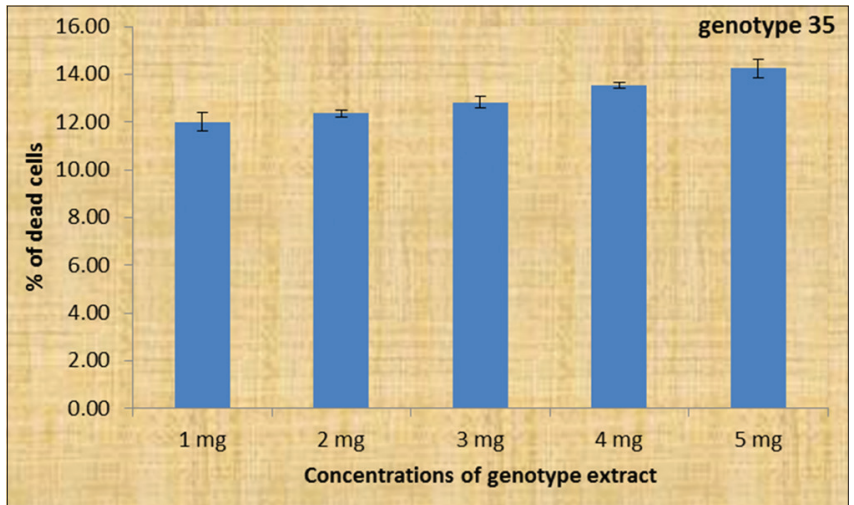

Fig. 6: Effect of different concentrations of genotype $G_{35}$ seed extract on the viability of Ehrlich ascites carcinoma cells

are important to include as part of a healthy diet. There are two main forms of unsaturated fatty acids, polyunsaturated such as linoleic acid, linolenic acid, and monounsaturated such as oleic acid. GLC analysis of FAME of the five genotypes of $G$. max showed that the total unsaturated fatty acid has higher values than a total saturated fatty acid. The highest value of total unsaturated fatty acids in the investigated genotypes was in $G_{82}(70.09 \%)$. The ascending order of total unsaturated fatty acid was $G_{82}(70.09 \%)>G_{111}(54.76 \%)>G_{35}(53.52 \%)>G_{22}(45.74 \%)>$ Crawford $(45.12 \%)$. The percentages of these fatty acids in soybean are considered to be unstable [25]. Two main types of polyunsaturated fats are omega- 3 fats and omega- 6 fats. There are three types of omega- 3 fatty acids involved in human physiology (linolenic, eicosapentaenoic, and docosahexaenoic acid). Linolenic acid was found in $G_{35}$ and $G_{111}$. The inhibition effect of omega- 3 fatty acids on tumor angiogenesis was reported [26]. Furthemore, omega-6 ( $\omega-6 \mathrm{~s})$ fatty acids such 
Table 10: Total content of secondary metabolites in the five genotypes extract of (G. max)

\begin{tabular}{llll}
\hline Genotypes & Determination & & \\
\cline { 2 - 4 } & Total phenolics (mg GAE/g DW) & Total flavonoids (mg QE)/g DW) & Total tannins (mg CE)/g DW) \\
\hline Genotypes & $7.35 \pm 0.19$ & & $0.91 \pm 0.04$ \\
$G_{82}$ & $8.48 \pm 0.15$ & $2.95 \pm 0.09$ & $1.00 \pm 0.06$ \\
$G_{22}$ & $9.38 \pm 0.22$ & $3.81 \pm 0.13$ & $1.07 \pm 0.10$ \\
$G_{111}$ & $9.99 \pm 0.19$ & $4.83 \pm 0.12$ & $1.19 \pm 0.07$ \\
Crawford & $11.90 \pm 0.19$ & $4.25 \pm 0.08$ & $1.49 \pm 0.17$ \\
\hline
\end{tabular}

GAE: Gallic acid equivalent, QE: Quercetin equivalent, CE: Catechin equivalent, G. max: Glycine max

Table 11: Summary of five different assays of antioxidant activity of G. max genotypes

\begin{tabular}{llllll}
\hline Genotype & DPPH\% & Absorbance at 700 $\mathbf{~ m m}$ & ABTS\% & Metal chelating \% & FRAP $(\boldsymbol{\mu m o l}$ Trolox/100 g DW) \\
\hline $\mathrm{G}_{82}$ & $30.98 \pm 0.42$ & $0.297 \pm 0.005$ & $37.72 \pm 0.57$ & $42.87 \pm 0.27$ & $1740 \pm 18.50$ \\
$\mathrm{G}_{22}$ & $29.59 \pm 0.50$ & $0.342 \pm 0.012$ & $39.34 \pm 0.37$ & $47.89 \pm 0.46$ & $2118 \pm 30.30$ \\
$\mathrm{G}_{111}$ & $30.27 \pm 0.88$ & $0.320 \pm 0.007$ & $37.27 \pm 0.35$ & $50.34 \pm 0.21$ & $2201 \pm 11.50$ \\
Crawford & $28.24 \pm 0.69$ & $0.327 \pm 0.008$ & $37.80 \pm 0.22$ & $51.23 \pm 0.20$ & $1977 \pm 17.20$ \\
$\mathrm{G}_{35}$ & $35.95 \pm 0.32$ & $0.509 \pm 0.008$ & $54.59 \pm 0.50$ & $61.54 \pm 0.57$ & $2913 \pm 26.80$ \\
\hline
\end{tabular}

Each value are mean of three replicates \pm standard deviation, G. max: Glycine max, DPPH: 2,2-diphenyl, 1-picryl hydrazyl, FRAP: Ferric reducing antioxidant power, ABTS: 2,2'-Azino-bis (3-ethylbenzothiazoline-6-sulphonic acid

Table 12: Effect of different concentrations of the five genotypes on the viability of EACC

\begin{tabular}{|c|c|c|c|c|c|}
\hline \multirow[t]{2}{*}{ Genotypes } & \multicolumn{5}{|c|}{ Dead cells \% } \\
\hline & $1 \mathrm{mg}$ & $2 \mathrm{mg}$ & $3 \mathrm{mg}$ & $4 \mathrm{mg}$ & $5 \mathrm{mg}$ \\
\hline $\mathrm{G}_{82}$ & $3.79 \pm 0.13$ & $4.96 \pm 0.17$ & $5.15 \pm 0.15$ & $6.02 \pm 0.11$ & $6.64 \pm 0.14$ \\
\hline $\mathrm{G}_{22}$ & $3.27 \pm 0.12$ & $3.55 \pm 0.14$ & $3.64 \pm 0.15$ & $4.07 \pm 0.09$ & $5.80 \pm 0.16$ \\
\hline $\mathrm{G}_{111}^{22}$ & $7.47 \pm 0.24$ & $8.37 \pm 0.30$ & $8.80 \pm 0.14$ & $9.79 \pm 0.15$ & $10.36 \pm 0.19$ \\
\hline Crawford & $11.83 \pm 0.14$ & $11.97 \pm 0.09$ & $12.15 \pm 0.09$ & $12.49 \pm 0.19$ & $13.18 \pm 0.15$ \\
\hline $\mathrm{G}_{35}$ & $12.00 \pm 0.40$ & $12.35 \pm 0.14$ & $12.83 \pm 0.24$ & $13.53 \pm 0.13$ & $14.25 \pm 0.38$ \\
\hline
\end{tabular}

Data are means of triplicate experiments \pm standard deviation, EACC: Ehrlich ascites carcinoma cells

as linoleic and arachidonic acid were recorded in our work. The $\omega-6 s$ have been shown to exert anticancer proliferation effects by influencing gene and protein expression by disrupting cell cycle progression and inducing apoptosis. Linoleic acid was present in $G_{35}$, $\mathrm{G}_{82}$, and $\mathrm{G}_{111}(\mathrm{r}: 36.99-44.80 \%$ ) Arachidonic acid which presents only in $\mathrm{G}_{111}(0.82 \%)$. Omega-6 fatty acids have possessed diverse bioactivities and are associated with many beneficial effects on human health including cancer development [27]. Recently [28], omega-3 ( $\omega-3)$ polyunsaturated fatty acids were reported to protect Sertoli cells apoptosis at the physiologically relevant levels [28]. In our present work, the glutamic acid concentration in all genotypes is the highest values in all identified amino acids. The range of glutamic acid was within 23.387-13.396\%. Glutamic acid, a non-essential amino acid, is highly abundant amino acid found in most foodstuffs and comprise between 5 and $15 \%$ of dietary protein [29]. It is a non-essential amino acid. The non-essential amino acid is produced in the body from other substances, so the body does not require a dietary intake of glutamic acid [30]. Glutamic acid is mostly metabolized in the brain, and this substance is an essential neurotransmitter which is essential for normal healthy brain function [31].

There was wide variation in the composition of phytochemicals in the five G.max genotypes detected by GC/MS. $\mathrm{G}_{35}$ had the highest number of aldehydes, phenolics, ketones, esters, alcoholics, and carboxylic. $G_{22}$ had the highest number of esters, carboxylic, and alkanes. $G_{82}$ had the highest number of heterocyclic and ester compounds. $G_{111}$ had the highest number of aldehydes, alkanes, esters, and other valuable compounds possessing powerful radical scavenging activity, suggesting the correlation with antiproliferative activity $[32,33]$. Phenolics inhibit carcinogenesis by influence on the molecular events in the initiation, promotion, and progression stages [34]. HPLC analysis of isoflavone aglycones is the most performing technique for qualitative analysis of G. max isoflavones. It can make a fingerprint of soybean extracts thought the content of isoflavone aglycones. The photo-diode-array detection was used over a wavelength range $260 \mathrm{~nm}$ to collect spectral data. The major form of flavonoids in soybean seeds is isoflavone; it has many chemical actions such as antioxidative and anticancer agents [35]. In our comparative study, $G_{35}$ which is local genotype had a higher value of detected isoflavone aglycones than genotype Crawford which was imported from the USA. The impact of dietary isoflavones, daidzein, and genistein, on the health of adults, and infants is well known [36]. Isoflavones are categorized chemically by their functional groups. Recently [37], a study reported that the genotype $\mathrm{G}_{111}$ showed the lowest phenolic content $(1.15 \mathrm{mg} / \mathrm{g})$ while the genotype Romal-1 was of the highest value $(1.7 \mathrm{mg} / \mathrm{g})$ compared with the other hybrids. The range of total flavonoids $(0.68-2.13 \mathrm{mg} \mathrm{QE} / \mathrm{g})$ and total phenolics (1.15-1.77 mg GAE/g) showed great variability between the investigated genotypes [32,37]. Many studies suggested that the majority of chemical components significantly depend on both genetic and environmental factors, with a large influence derived from temperature, water, nutrient supply, and other factors [32,37]. In our study, genotype $G_{35}$ showed a large class of secondary plant metabolites of different structures such as aldehydes, phenolics, ketones, esters, alcoholics, and carboxylic. Other phtyoconstituents as unsaturated fatty acids, sterols and/or triterpenes, and polyphenols were inconsiderable amount in all the studied genotypes. These detected compounds have valuable effect as antitumor and antioxidant agents [38,39]. The consumption of plants rich in polyphenol compounds has been linked with inhibitory and preventive effects in various human cancers and cardiovascular diseases, which may be related to the antioxidant activity of polyphenols [40]. In the present paper, HPLC-PDA analysis showed the presence of isoflavone aglycones; daidzein, glycitein, and genistein in both genotypes. Genistein had been reported that it can act by both hormonal and non-hormonal action in the inhibition of cancer and act as 
antioxidant compound [41,42]. $\mathrm{G}_{35}$ showed high chemical composition of phenolics, flavonoids, and tannins in comparison with other genotypes and that might be responsible for their comparatively higher antioxidant activity $[39,42]$. In our study, DPPH and $\mathrm{ABTS}^{+}$scavenging methods have been used to evaluate the antioxidant activity of extracts due to the simple, rapid, sensitive, and reproducible procedure [43]. $\mathrm{G}_{35}$ showed the highest radical scavenging and antioxidant capacity using five analytical assays (Table 11) compared with the reference antioxidant radical scavenger compounds BHT and Trolox. It followed by $G_{22}$ in two methods; reducing power ability and ABTS radical scavenging activity. The results showed that $\mathrm{G}_{35}$ had the highest content of phenolics and flavonoids as well as the antioxidant activity. A positive result was observed between the antioxidant activity potential and total flavonoids level of the genotype extracts. The results of this study explore the potential of $G_{35}$ and $G_{22}$ as a rich source of natural antioxidants for the development of functional foods and nutraceutical applications. The strong correlation was observed between antioxidant capacities and their total phenolic contents. In parallel with our results, Prakash et al. [44] suggested the high antioxidant activity (50.5-74.7\%) may be linked to high polyphenols content (52.7-81.7 mg GAE/g GAE) of soybean Hara genotypes. The previous study reported the structureactivity relationship of antioxidant and antitumor polyphenols [45]. Inhibitions of tumor initiation and promotion, which are affected by antioxidant and binding activities, are exhibited in various potencies, being influenced by the structure and molecular weight of polyphenols as tannins [45]. Concerning the antitumor activity of G. max genotypes, all the samples especially $G_{35}$ have showed remarked antitumor activity against carcinogenic cells. Soybean isoflavone intake exerts a protective effect against postmenopausal breast cancer, the overexpression of human epidermal growth factor receptor 2 promotes the malignant transformation of breast epithelial cells [46]. Sugiyama et al. [47] demonstrated that daidzein converted to a metabolite called equol by intestinal bacteria leads to a significantly reduced risk of prostate cancer.

Our results indicated that the tested genotypes showed substantial differences in terms of chemical composition, antitumor, and antioxidant activities. The results confirm the higher value of phytoconstituents of the genotype $G_{35}$ and $G_{21}$ as well as their better bioactivity. $G_{35}$ which is local genotype had the highest value of total phenolics, flavonoids, and tannins also this genotype showed highest antioxidant activity evaluated by the five assays and antitumor activity which found to be $14.25 \pm 0.38$ at concentration $5 \mathrm{mg} / \mathrm{mL}$.

\section{CONCLUSION}

The results confirm the higher value of phytoconstituents of the genotype Giza 35 and Giza 21 as well as their better bioactivity. Hence, we recommended to use these genotypes as they had healthy fats and can be included as part of a healthy diet.

\section{AUTHOR'S CONTRIBUTIONS}

Howaida I. Abd-Alla: Plan of work, chemical composition study, writing, revision, and corresponding author. Hanan A. Taie: Plan of work, biological activities study, writing, and revision. Marwa M. AbdElmotaleb: Samples preparation and share of the practical study.

\section{CONFLICTS OF INTEREST}

The authors have none to declare.

\section{REFERENCES}

1. Gomes LS, Senna R, Sandim V, Silva-Neto MA, Perales JE, Zingali RB, et al. Four conventional soybean [Glycine $\max (\mathrm{L}$.) Merrill] seeds exhibit different protein profiles as revealed by proteomic analysis. J Agric Food Chem 2014;62:1283-93.

2. Butler LM, Wu AH, Wang R, Koh WP, Yuan JM, Yu MC, et al. A vegetable-fruit-soy dietary pattern protects against breast cancer among postmenopausal Singapore Chinese women. Am J Clin Nutr 2010;91:1013-9.
3. Matsumura K, Tanaka T, Kawashima H, Nakatani T. Involvement of the estrogen receptor beta in genistein-induced expression of p21(waf1/ cip1) in PC-3 prostate cancer cells. Anticancer Res 2008;28:709-14.

4. MacDonald RS, Guo J, Copeland J, Browning JD Jr. Sleper D, Rottinghaus GE, et al. Environmental influences on isoflavones and saponins in soybeans and their role in colon cancer. J Nutr 2005; 135:1239-42

5. Ma DF, Qin LQ, Wang PY, Katoh R. Soy isoflavone intake increases bone mineral density in the spine of menopausal women: Meta-analysis of randomized controlled trials. Clin Nutr 2008;27:57-64.

6. Ponnusha BS, Pasupathi P, subramaniyam B, Virumandy SR. A complete evaluation of the antioxidant and antimicrobial potential of Glycine max. Int J Cur Sci Res 2011;1:6-12.

7. Association of Official Analytical Chemists. Official Methods of Analysis. $15^{\text {th }}$ ed. Washington DC., USA, Association of Official Analytical Chemists; 1990.

8. Johnson AR, Davenport JB. Biochemistry and Methodology of Lipids. New York: John Wiley and Sons Inc.; 1971. p. 31

9. Iverson JL, Sheppard AJ. Programmed temperature gas chromatographic analysis of esters of fatty acids. J Chromatogr Sci 1975;13:505-8

10. Adams RP. Identification of Essential Oils by Ion Trap Mass Spectroscopy. New York: Academic Press Inc.; 1995.

11. Jennings W, Shibamato T. Qualitative Analysis of Flavor and Fragrance Volatiles by Glass Capillary Gas Chromatography. New York: Academic Press; 1981.

12. Meda A, Lamien CE, Romito M, Millogo J, Nacoulma OG. Determination of the total phenolic, flavonoid and proline contents in Burkina Fasan honey, as well as their radical scavenging activity. Food Chem 2005;91:571-7.

13. Ordoñez AA, Gomez JD, Vattuone MA, 1sla MI. Antioxidant activities of Sechium edule (Jacq.) Swartz extracts. Food Chem 2006;97:452-8.

14. Maxon ED, Rooney LW. Evaluation of methods for tannin analysis in Sorghum grain. Cereal Chem 1979;49:719-729.

15. Klejdus B, Mikelová R, Petrlová J, Potesil D, Adam V, Stiborová M, et al. Evaluation of isoflavone aglycon and glycoside distribution in soy plants and soybeans by fast column high-performance liquid chromatography coupled with a diode-array detector. J Agric Food Chem 2005;53:5848-52.

16. Brand-Williams W, Cuvelier ME, Berset C. Use of a free radical method to evaluate antioxidant activity. LWT 1995;28:25-30.

17. Oyaizu M. Studies on the product of browning reaction prepared from glucosamine. Nutrition 1986;44:307-15.

18. Dinis TC, Maderia VM, Almeida LM. Action of phenolic derivatives (acetaminophen, salicylate, and 5-aminosalicylate) as inhibitors of membrane lipid peroxidation and as peroxyl radical scavengers. Arch Biochem Biophys 1994;315:161-9.

19. Re R, Pellegrini N, Proteggente A, Pannala A, Yang M, Rice-Evans C, et al. Antioxidant activity applying an improved ABTS radical cation decolorization assay. Free Radic Biol Med 1999;26:1231-7.

20 Benzie IF, Strain JJ. Ferric reducing/antioxidant power assay: Direct measure of total antioxidant activity of biological fluids and modified version for simultaneous measurement of total antioxidant power and ascorbic acid concentration. Methods Enzymol 1999;299:15-27.

21. El-Merzabani MM, El-Aaser AA, Attia MA, El-Duweini AK, Ghazal AM. Screening system for Egyptian plants with potential antitumour activity. Planta Med 1979;36:150-5

22. Silva A, Ciabotti S, Juhasz A, Mendonça C, Tavano O, Mandarino J, et al. Chemical composition, protein profile, and isoflavones content in soybean genotypes with different seed coat colors. Int Food Res J 2016;23:621-9.

23. Bhardwaj HL, Bhagsari AS, Joshi JM, Rangappa M, Sapra VT, Rao MS. Yield and quality of soymilk and tofu made from soybean genotypes grown at four locations. Crop Sci 1999;39:401-5.

24. Vieira CR, Cabral LC, Paula AC. Proximate composition and amino acid, fatty acid and mineral contents of six soybean cultivars for human consumption. Pesqui Agropecu Bras 1999;34:1277-83.

25. Neff WE, List GR. Oxidative stability of natural and randomized high palmitic and high-stearic acid oils from genetically modified soybean varieties. J Am Oil Chem Soc 1999;76:825-31.

26. Spencer L, Mann C, Metcalfe M, Webb M, Pollard C, Spencer D, et al. The effect of omega-3 FAs on tumour angiogenesis and their therapeutic potential. Eur J Cancer 2009;45:2077-86

27. Xu Y, Qian SY. Anti-cancer activities of $\omega-6$ polyunsaturated fatty acids. Biomed J 2014;37:112-9.

28. Hu X, Ge X, Liang W, Shao Y, Jing J, Wang C, et al. Effects of saturated palmitic acid and omega-3 polyunsaturated fatty acids on sertoli cell apoptosis. Syst Biol Reprod Med 2018;64:368-80. 
29. Li X, Rezaei R, Li P, Wu G. Composition of amino acids in feed ingredients for animal diets. Amino Acids 2011;40:1159-68.

30. Wernerman J. Clinical use of glutamine supplementation. J Nutr 2008:138:2040S-2044S

31. Meldrum BS. Glutamate as a neurotransmitter in the brain: Review of physiology and pathology. J Nutr 2000;130:1007S-15S.

32. Taie HA, Abd-Alla HI, Ali SA, Aly HF. Chemical composition and biological activities of two Solanum tuberosum cultivars grown in Egypt. Int J Pharm Pharm Sci 2015;7:311-20.

33. El-baz FK, Hassan AZ, Abd-Alla HI, Aly HF, Mahmoud K. Phytochemical analysis, assessment of antiproliferative and free radical scavenging activity of Morus alba and Morus rubra fruits. Asian J Pharmaceut Clin Res 2017;10:189-99.

34. Yang CS, Landau JM, Huang MT, Newmark HL. Inhibition of carcinogenesis by dietary polyphenolic compounds. Annu Rev Nutr 2001;21:381-406.

35. Mohamed NZ, Abd-Alla HI, Aly HF, Mantawy M, Ibrahim N, Hassan SA. $\mathrm{CCl}_{4}$-induced hepatonephrotoxicity: Protective effect of nutraceuticals on inflammatory factors and antioxidative status in rat. J Appl Pharm Sci 2014:4:87-100

36. Anthony MS, Clarkson TB, Hughes CL Jr. Morgan TM, Burke GL. Soybean isoflavones improve cardiovascular risk factors without affecting the reproductive system of peripubertal rhesus monkeys. J Nutr 1996;126:43-50

37. Alghamdi SS, Khan MA, El-Harty EH, Ammar MH, Farooq M, Migdadi HM, et al. Comparative phytochemical profiling of different soybean (Glycine max (L.) Merr) genotypes using GC-MS. Saudi J Biol Sci 2018;25:15-21.

38. Abu-Gabal NS, Abd-Alla HI, Mohamed NZ, Aly HF, Shalaby NM. Phytophenolics composition, hypolipidemic, hypoglycemic and antioxidative effects of the leaves of Fortunella japonica (Thunb.) swingle. Int J Pharm Pharm Sci 2015;7:55-63.
39. Awad HM, Abd-Alla HI, Mahmoud KH, El-Toumy SA. In vitro antinitrosative, antioxidant, and cytotoxicity activities of plant flavonoids: A comparative study. Med Chem Res 2014;23:3298-307.

40. Sales PM, Souza PM, Simeoni LA, Silveira D. A-amylase inhibitors: A review of raw material and isolated compounds from plant source. J Pharm Pharm Sci 2012;15:141-83.

41. Barnes S, Peterson, G, Grubbs C, Setchell, K. Potential role of dietary isoflavones in the prevention of cancer, Adv Exp Med Biol 1994;354:135-47.

42. Lee J, Renita M, Fioritto RJ, St Martin SK, Schwartz SJ, Vodovotz Y, et al. Isoflavone characterization and antioxidant activity of Ohio soybeans. J Agric Food Chem 2004;52:2647-51.

43. Özcelik B, Lee JH, Min DB. Effects of light, oxygen and $\mathrm{pH}$ on the 2, 2-diphenyl-1-picrylhydrazyl (DPPH) method to evaluate antioxidants. J Food Sci 2003;68:487.

44. Prakash D, Upadhyay G, Singh BN, Singh HB. Antioxidant and free radical-scavenging activities of seeds and agricultural wastes of some varieties of soybean (Glycine max). Food Chem 2007;104:783-90.

45. Okuda T. Structure-activity relationship of antioxidant and antitumor polyphenols. In: Ohigashi $\mathrm{H}$, Osawa $\mathrm{T}$, Terao $\mathrm{J}$, Watanabe $\mathrm{S}$, Yoshikawa T, editors. Food Factors for Cancer Prevention. Tokyo: Springer; 1997. p. 280-5.

46. Wada K, Nakamura K, Tamai Y, Tsuji M, Kawachi T, Hori A, et al. Soy isoflavone intake and breast cancer risk in japan: From the Takayama study. Int J Cancer 2013;133:952-60.

47. Sugiyama A, Yamazaki Y, Yamashita K, Takahashi S, Nakayama T, Yazaki $\mathrm{K}$, et al. Developmental and nutritional regulation of isoflavone secretion from soybean roots. Biosci Biotechnol Biochem 2016;80:89-94. 